\title{
Reacting to the Powers that Be: Investigations of a Calabrian, Post-Medieval Community
}

\author{
Paula Kay Lazrus
}

Published online: 20 December 2013

C The Author(s) 2013. This article is published with open access at Springerlink.com

\begin{abstract}
The town of Bova (Calabria, Italy) is a post-medieval montane community that remained inaccessible well into the twentieth century. Archival research, field survey, and spatial analyses provide a foundation for investigating the effects of social and political restructuring on the economic and social development of the community. Attitudes of laxness, disinterest, or ignorance have been attributed to inhabitants of this region. They can be interpreted as projected upon the citizens of Bova and others in southern Calabria by those in more urban centers to the north. Potentially, they reflect preferred survival strategies in the face of shifting imperial control.
\end{abstract}

Keywords Calabria $\cdot$ Archaeology $\cdot$ Post-medieval $\cdot$ Landscape $\cdot$ Colonialism

\section{Introduction}

The southern Calabrian municipality of Bova, in the foothills of the Aspromonte, is the location for an ongoing investigation into life in a small post-medieval montane community. This paper presents an initial attempt to achieve a deeper understanding of the socioeconomic lives of Bovans utilizing the territory in the more recent past, by integrating information from the Napoleonic cadaster-the Catasto Murattianodrawn up in 1807-08 with other archival documents and data from archaeological field survey. Historical material from this area of Italy is often rejected as not being old or unique enough for in depth study. Disentangling the lives of people in Bova's territory and their use of the land is further complicated by the lack of a stratigraphic chronology. This is the first study in this region of Italy to try integrating archaeological and archival data for this time period and it provides a window into the lives of people in post-medieval Calabria that has been of scant interest to researchers (Athanassopoulos 2004; Galt 1991; Robb 1997). This work focuses primarily on data from the period in which southern Calabria was briefly under Napoleonic (French) rule

P. K. Lazrus $(\bowtie)$

Institute of Core Studies, St. John's University, Bent Hall 347, 8000 Utopia Parkway, Queens, NY 11439,

USA

e-mail: Lazrusp@stjohns.edu 
between episodes of Bourbon (Spanish) control (1806-15). Survival strategies developed during its prolonged colonial period (starting with the Normans in $1000 \mathrm{CE}$ ) extend into the period of unification (1861 when Italy formally became a single political entity) and further to the present.

Bova's territory prior to the twentieth century was significantly larger than it is today. It covered $300 \mathrm{~km}^{2}$ versus the $76.40 \mathrm{~km}^{2}$ for the combined municipalities of Bova and Bova Marina today. It controlled a territory inhabited since the Neolithic (Foxhall 2006; Robb 1999). During the post-medieval period most inhabitants lived in the town of Bova itself (C. ASRC 1807). There were also citizens who lived in small administratively dependent communities and in more isolated farmsteads or seasonal habitations located throughout the landscape (Figs. 1 and 2).

Bova's relatively isolated location may have played a role in the development of its independent identity as may its historical position as a bishopric. The town was also tied to the larger social and political systems as part of the Kingdom of Naples. Nonetheless, shifting political regimes (i.e., alternating Bourbon and Napoleonic rule until Unification), were disruptive. In addition, the inhabitants of southern Calabria suffered natural calamities on a regular basis. These contributed to periodic famines and epidemics which led to economic upheavals and social and political restructuring (Postpichi 1985; Rao 1992). Natural events and the political responses to them influenced the way Bovan citizens chose to respond to shifting requests from the imperial capital, Naples. A desire to maintain some control over their livelihoods contributed to a strategy of passive aggressive responses to taxation, improving transportation infrastructure or engaging in forms of commerce that would otherwise have created stronger external relationships. It is the interplay of data, lack of postmedieval infrastructure in the form of paved roads, easily accessible mills or processing structures and tax data that lead to this understanding.

While Bova's territory may initially appear abandoned or underutilized, it is better understood as reflective of the inhabitants' fluctuating patterns of usage given the shifting demands of distant political administrations and individual risk assessments. As a discipline, our understanding of such landscapes has grown deeper and more nuanced over the years as survey techniques and spatial analysis have allowed for new interpretations of archaeological and historical data. The work of Forbes, Davies and Davis, and others provide excellent examples of work that derives understanding about past communities in this manner (Athanassopoulos 2010; Barker 1995; Davies and Davis 2007; Doorn 1985; Dyson and Rowland 2007; Forbes 2007a; Given 2004). Recent studies of Nemea, Ottoman Greece, Northern Ireland, and Apulian Italy have illustrated that modern archaeology's integration of archival and field research can contribute to a greater understanding of how people have engaged with the landscape (Athanassopoulos 2010; Barker 1995; Galt 1991; Horning 2007; Zarinebaf et al. 2005). Despite a largely underutilized and apparently abandoned landscape, Bova's territory is in fact quite active. It has a recurring life cycle during which some areas are in greater use than others, but which is rarely if ever truly abandoned. Some of these fluctuations are local and dependent on natural cycles of drought, disease and natural calamity. Other influences were more political, reflecting relationships between the hinterland and the political center located in Naples. These relationships were fluid and regularly redefined as necessary (van Dommelen 1997, p. 309). Wide-ranging excavation and survey projects like the Bova Marina Archaeological Project (BMAP) benefit from 


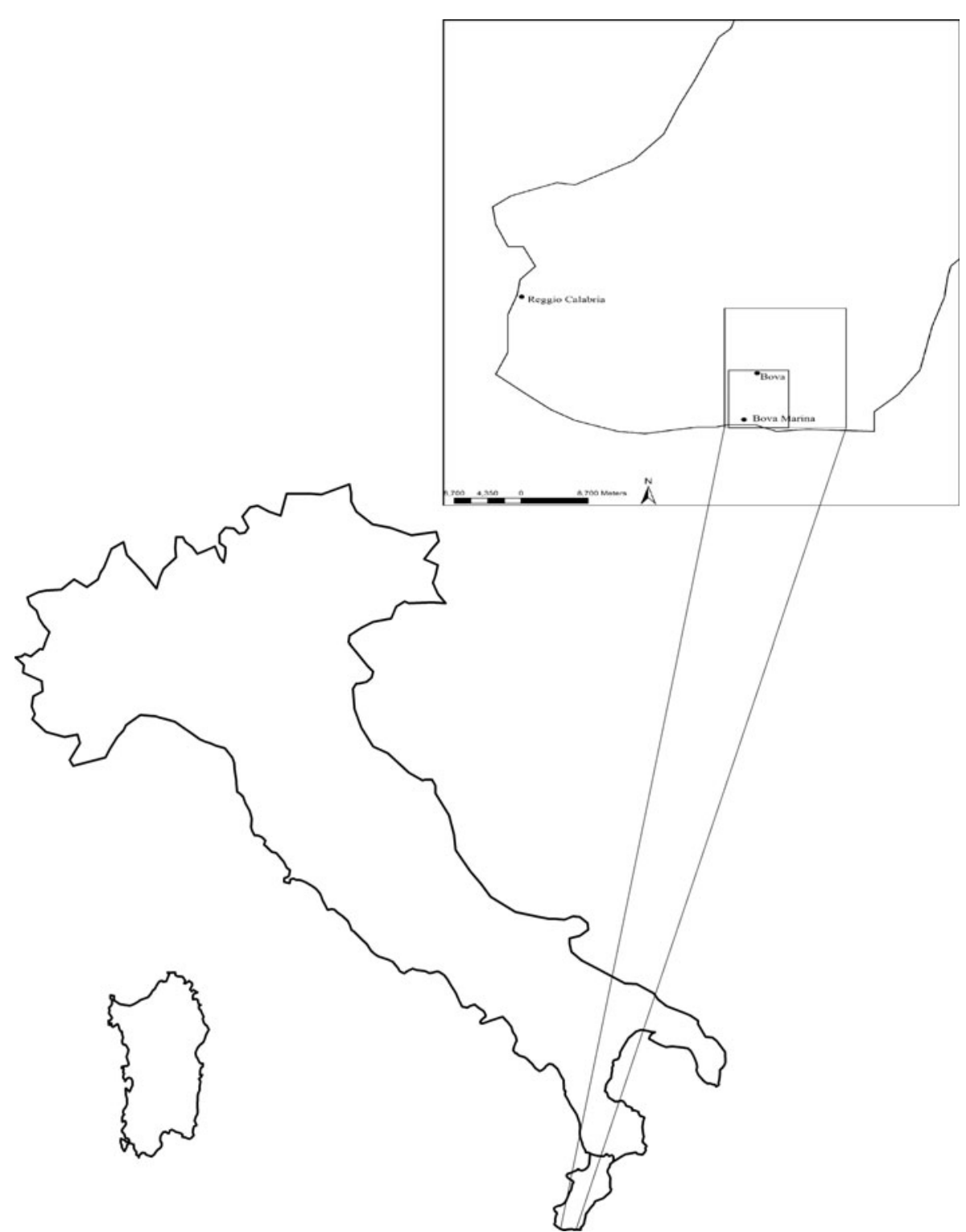

Fig. 1 Map of Italy. Calabria Ultra demarcated by dark line across outline. Area of Detail: Outer box illustrates the original limits of the municipality, the inner the contemporary limits

archival research that provides a deeper overall understanding of the continuum of land-use that in this area extends back to the Neolithic (Athanassopoulos and Wandsnider 2004; Barker 1995; Robb 1997; Zarinebaf et al. 2005).

The use of spatial analysis to understand the multilayered relationships among individuals, the landscape and larger cultural systems, artifacts, and structural features 

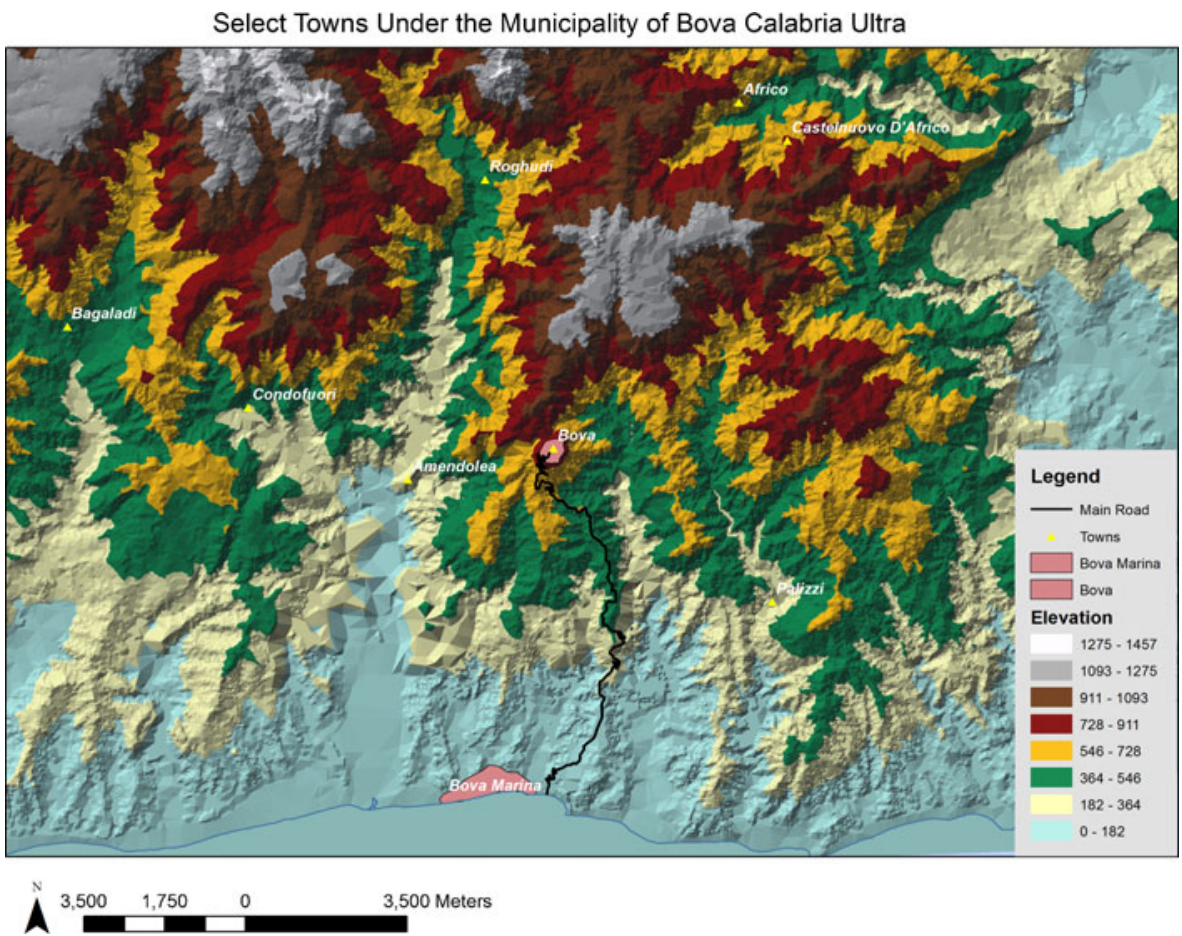

Fig. 2 Towns with citizens paying taxes to Bova

has a well-established history (Athanassopoulos 2010; Butzer 1982; Doorn 1985; Roberts 1996; Snead et al. 2009, pp. 3-4). Recent work understanding the archaeological footprint of colonial systems on early societies provides a useful entrée to examine the data available for southern Calabria in general and for Bova in particular (Davies and Davis 2007; Gaimster 2009; Given 2004; Van Dommelen 1997). Recent projects in Cyprus and Greece provide excellent examples of how attention to historical records combined with landscape analysis and traditional field work brings a deeper understanding to the long term history of communities previously only of interest for their more ancient pasts (Athanassopoulos 2010; Davis 1991; Forbes 2007a, b; Zarinebaf et al. 2005). Cadastral records, spatial analysis and field survey elucidate the connection between land-use and the political, social and economic conditions of the inhabitants.

In order to investigate the social, economic and environmental changes within the community of Bova this work integrates data from the first draft Napoleonic cadaster, the Catasto Murattiano of 1807-08 (C. ASRC 1807) with land-use analysis and field research conducted by the author and other members of BMAP. It represents a preliminary attempt to connect archival research with our archaeological survey work, although material from the project's field survey awaits a full detailed analysis. The original project design did not specifically provide for post-medieval landscape/archival studies (Foxhall et al. 2007; Lazrus 2006; Robb 1997; Yoon 2006, 2012). The absence of tight chronological resolution or comparative data sets of ceramics, small finds or construction materials from this part of Italy complicate the analysis. The similarities in style and composition for at least some of the ceramics and building 
materials exacerbates the problems, as local citizens often consider all of the postmedieval material equally "contemporary" and thus unworthy of interest or distinction. This complicates any attempt to interpret the spatial and temporal uses of the landscape and to integrate them forcefully with the archival material. Analysis of individual, municipal, and ecclesiastical land holdings, personal property logs, judicial complaints and notarized documents highlight the use, misuse and changing ownership of various plots of land from the late 1700 s until the early years of the twentieth century. Ideally, one would be able to read both the archaeological and archival record and thus to identify points of convergence or divergence. This work should shed light on the veracity of some of the historical records, or illuminate how they were manipulated. So too should the archaeological work lead to a greater understanding not only of resource and land-use, but of the economic well-being of the inhabitants. In fact, this is still very much a work in progress.

Successive maps of the territory indicate shifting boundaries. Fluid place names provide evidence of infrastructure or absence thereof, and changing vegetation all reflect the complex relationship between inhabitants and the land throughout the post-medieval period (Foxhall et al. 2007; Lazrus and Robb 1998; Lazrus 2005, 2006). An Annales-type approach, although complex, still provides a valid framework for distilling understanding from multiple streams of data, some of which are not chronologically precise (Athanassopoulos 2004). This approach has its merits within the context of a mixed archaeological/historical analysis within an environmental context. Here the archaeological data fits a time frame closer to Braudel's conjonctures, while the archival documents represent the narrower time frame of his evenementielle (Athanassopoulos 2004, pp. 85-87; Horden and Purcell 2000, p. 37).

How was this landscape perceived by the local inhabitants or the ruling parties in distant cities? How did the changing political regimes influence the relationship of the citizens of Bova to the landscape? Exploring the contemporary environment provokes questions about how people once lived and how they responded to the shifting demands of new political regimes and resource exploitation. It becomes possible to consider not only how the territory has been transformed and to corroborate older travel descriptions, but also to ponder the role of the local inhabitants (or groups of them) with regard to their colonial rulers in Naples. As only a small portion of the population was literate, archaeological evidence is all the more important for exploring the full development of the area, just as it is for the Prehistoric periods. This can provide a catalyst for an eventual reconsideration of land-use in the deeper past that can in turn shed new light on contemporary conditions. This approach enhances our insights into the lives of the inhabitants who by their location and relative political and social insignificance have been viewed as marginalized throughout their history (Athanassopoulos and Wandsnider 2004; Kasdagli 2007; Rocheleau et al. 1995).

The introduction of factories and industrial modes of production in the mid 17001800 s signaled the start of a new era in much of Europe, while Calabria Ultra, as this section of Calabria was called, was still functioning in a post-medieval, but preindustrial world (Gaimster 2009). At this time, 70-80 \% of Europe's population lived north of the Alps. In that region industrial changes began to take hold. In the south, and particularly the extreme south, citizens continued to live in an economy based on smallscale, rain-fed agriculture providing food for both people and animals driven by manual labor (Bizzocchi 2009, pp. 18, 22). As late as 1910, Italy lagged well behind its 
northern European neighbors in standard of living. Citizens in the southern part of Italy were generally $50 \%$ more disadvantaged than their compatriots in the north (Mitchell 2008). To some in the mid-late 1800 s this was proof of southern Italy's inability to compete in the modern world. I suggest it also reflects a realistic approach to life in an area potentially categorized as an appendage by Europe's political centers (Naples, Madrid, and Paris). Finally, it is important to recognize that Calabria, and even Calabria Ultra, is made up of very discrete ecological zones that have developed distinct agricultural, industrial, and contractual strategies and arrangements between owners and workers (Arlacchi 1983). The living and working conditions of inhabitants along the Tyrrhenian and Ionian coasts are diverse, as are conditions between Calabria Ultra and Calabria Citra. Even between communities only a few kilometers apart the differences in vegetation, topography and access to roads/trails make for diverse political and social arrangements (see Fig. 2).

\section{Archaeological and Archival Data Sets}

Since 1997 BMAP, in collaboration with the Soprintendenza Archeologica della Calabria, has been exploring the Bovese utilizing a combination of field survey and excavations (Robb 1997). To date, the project has explored roughly $10 \%$ of the area belonging to the current communities of Bova and Bova Marina which form the focus of our study area (Yoon 2012). The project was initiated by a desire to fill a regional lacuna. The Soprintendenza was looking for a professional investigation of materials that had been donated by local vocational archaeologists, and John Robb, then of Southhampton University, and the late Jon Morter, sought to respond by developing a project with a broad scope to investigate settlement in this area with a particular focus on the Neolithic (Robb 1997). Southern Calabria has received much less attention than other areas of southern Italy, particularly with regard to the prehistoric period. Aside from the Classical period, archaeological investigations in this part of Italy have been rare. Perhaps this is because the region has many fewer preserved artifacts compared to those that surround it, well under the low end counts found in comparable Greek projects (Foxhall et al. 2007, p. 21). The early seasons focused almost exclusively on exploring sites and issues related to the use of the territory in prehistory. The Classical and later periods were added afterwards (Foxhall et al. 2007). The initial focus on Neolithic society, culture, and interaction gradually expanded to include explorations of those facets of settlement from prehistory down to the contemporary period.

In addition to field survey BMAP has conducted six relatively small-scale excavations; two each have focused on the Neolithic, Bronze Age, and Classical Greek periods. Our field survey has been more diachronic, if not always consistent in the collection of post-medieval materials (see BMAP reports posted to the excavation website, Bova Marina Archaeological Project 2011).

Depending on the year and the available resources the field survey was conducted by small crews (averaging three-five persons) who walked parcels referred to as "areas." Areas are defined by the local topography and conditions of access (locked fences versus open fields or otherwise inaccessible units). Existing field boundaries were used where possible. The areas ranged from 0.1 to 4.3 ha and were walked systematically with crew members at $10-\mathrm{m}$ intervals wherever possible. Where dense clusters of 
materials could be identified as sites, more intensive collections were undertaken as separate units with their own records (Yoon 2006). Information was recorded regarding artifacts, local topography, and vegetation with some variation in the details captured by different crews. The collecting and recording of post-medieval materials, however, was erratic. Nothing from that period was explicitly targeted in the first two seasons, although some artifacts may have made it into the collections without any clear classifications. Later, especially after 2005, more attention was given to the postmedieval period, both standing structures and artifacts, although again, there was no systematic attempt to collect or record this material (Yoon 2012). This is in part a consequence of not collecting large quantities of construction materials that many thought were contemporary. Yoon (2012) has acknowledged that the general lack of interest in later historical archaeology in this part of Italy has complicated his attempts at analyzing these materials. Nevertheless, he has completed an initial classificatory scheme. I plan to validate this through future excavation work on the remains of several rural houses in our area. Until we have strong stratigraphic and chronological data for the materials, it will remain difficult to analyze what we have collected and to come to understand its distribution and use.

The lack of attention to the post-medieval period on the part of BMAP reflects an initial strategy that was focused on understanding the prehistoric landscape despite the practice of broader collection strategies common in other parts of the Mediterranean (Athanassopoulos 2010; Davies and Davis 2007; Gibson 2007; Lazrus 1992). Because the archival research began after our survey strategies were defined, the link between localities with abundant cadastral data and field areas walked is not always precise. Post-medieval remains consisting primarily of remnant features such as houses or terraces and copious amounts of roof tile have been found in roughly $75 \%$ of survey areas despite the lack of formal strategies to record and collect this material (Yoon 2012). Sometimes roof tile and bricks were collected from survey areas. At other times, materials were counted or simply noted on field records. These two categories of materials make up the bulk of post-medieval remains that also include several types of ceramics. Dating of all these artifacts remains rudimentary at present (Fig. 3), and none of the post-medieval material has been drawn, photographed or published yet.

While it is true that significant progress has been made over the last 25 years or so in understanding the typologies and contexts of medieval ceramics in Italy, post-medieval materials are, with few exceptions, still inadequately understood (Arlacchi 1983; Galt 1991; Gelichi and Librenti 2007). This remains particularly true in southern Calabria. Whether we are discussing tableware or construction material (bricks, roof tiles, walls or terraces), there is little that has been systematically published (Manacorda 1985; Manzi and Ruggiero 1987). The tendency in Southern Calabria has been to consider all post-medieval material "modern," in the sense of contemporary (thus less worthy of attention). Yoon's classification scheme for the artifacts from BMAP divides the artifacts into three groups: Modern I (1500-1800), II (1801-1970), and III (post 1970) (Yoon 2012).

In order to connect our field data with other historical materials it is necessary to link our collection areas with those localities referenced in available documents. Mapping the named locations in the tax record to physical areas on the ground has however proved challenging. The cadaster of 1807 reveals 400 localities (including likely duplicates). The descriptive qualities of many of the place names surely rendered them 


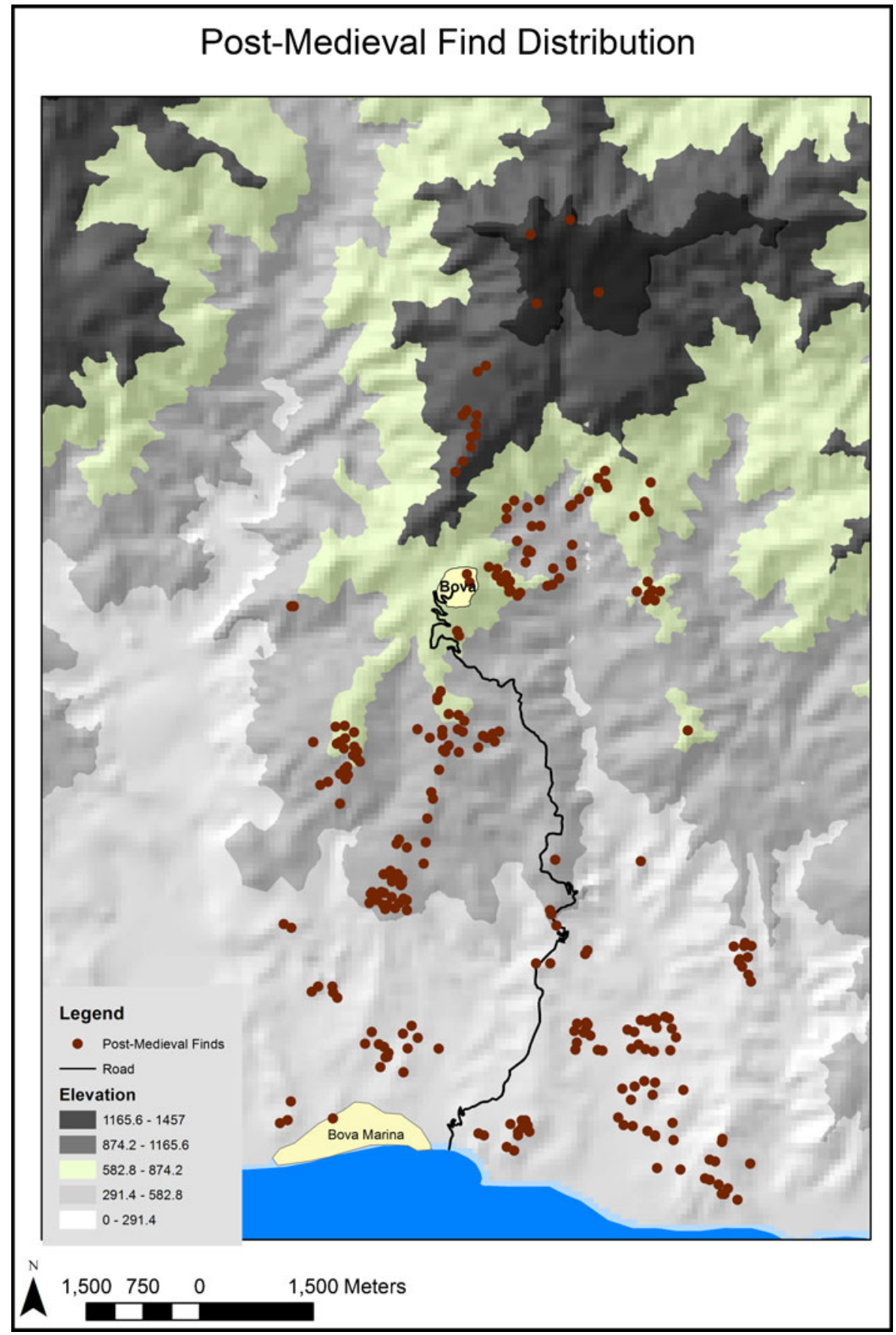

Fig. 3 Medieval finds distribution

self-evident to those using them at the time. Today, however, their meanings are less obvious, a challenge also encountered by other projects integrating archival materials 
with post-medieval landscape analysis (Zarinebaf et al. 2005, p. 5). Of the names listed in the cadaster I have been able to map over 40 localities, but the process of verification is on-going.

To create a sample group for spatial analysis for this initial GIS mapping of crops, land-use and standing structures, I used localities named in the cadaster that could be identified on available 1:25000 or 1:10000 maps and that had boundary references from the remnant sheets of the first official parcel map (1932). This resulted in a group of 40 mapped localities with another seven localities mapped in approximate fashion. While the aforementioned issues have complicated attempts to understand how people have utilized the land in the period examined, one must have a starting point. This study is the first step in trying to understand the lives of the people in this area in a systematic fashion (Fig. 4).

At the commencement of work in the late 1990s we observed a landscape often devoid of surface vegetation and developing badlands in some areas (Figs. 5 and 6). When this occurred is of course of interest. Is this a phenomenon of the last 50 years, a century or is it older? Forests, once said to have covered much of the uplands, are no longer in evidence to the south and southeast of Bova, and in some cases, erosion has removed much of the topsoil (Lazrus and Robb 1998). RAF aerial photos from 1943 clearly indicate that the loss of vegetative cover goes back at least to that period. Changes have continued apace with the bulldozing of new dirt tracks and terraces, the paving of existing roads and the fencing of lands. Terraces have been planted with olive groves and vineyards at an accelerating rate in the last 5 years largely due to an infusion of EU funds. These activities have transformed the landscape in profound ways, among them complicating access to some areas previously surveyed, occasionally inhibiting ground-truthing of GIS mapping and the further integration of archival data with our field data. It has not always been possible to return to survey areas with references to post-medieval materials/structures but lacking pictures or artifact collection.

The nineteenth-century tax documents created under Napoleon's brief rule recorded property by tracking the ownership of land and structures, utilized or not. Maps and legal and private documents pertaining to the municipality of Bova and its citizens, provide additional insights. These are housed primarily in the Archivo di Stato di Reggio (1800s-present) and the Archivo Nazionale di Napoli (pre-1800s). The personal and legal documents pertaining to Bova and held in the Reggio archive are organized into folders by inventory number. They contain a wide variety of materials including diary pages, receipts, contracts, complaints, official notices, balance sheets, and newspaper articles. They are generally neither catalogued individually nor paginated. Some folders may contain a single item, others ten to hundreds of pages.

The principle document utilized in this analysis is the previously mentioned Catasto Murattiano. It is comprised of two volumes with 1,024 entries. Entries are for individuals, groups of individuals or organizations who paid taxes (or were exempted from them) in 1807-08. At that time the territory was considerably more extensive than it is today (see Fig. 1). Crops, land, and structures belonging to citizens, the municipality or the church were all taxable. The municipality was a medium-sized stakeholder. The vast majority of entries for individuals represent men, although there are also individual women listed (C. ASRC 1807). Those with long term rentals (emphyteusis) or other contracts were not specifically differentiated (Assante 1997). Each individual (or group if something was owned collectively) was listed with entries for each item owned, the 


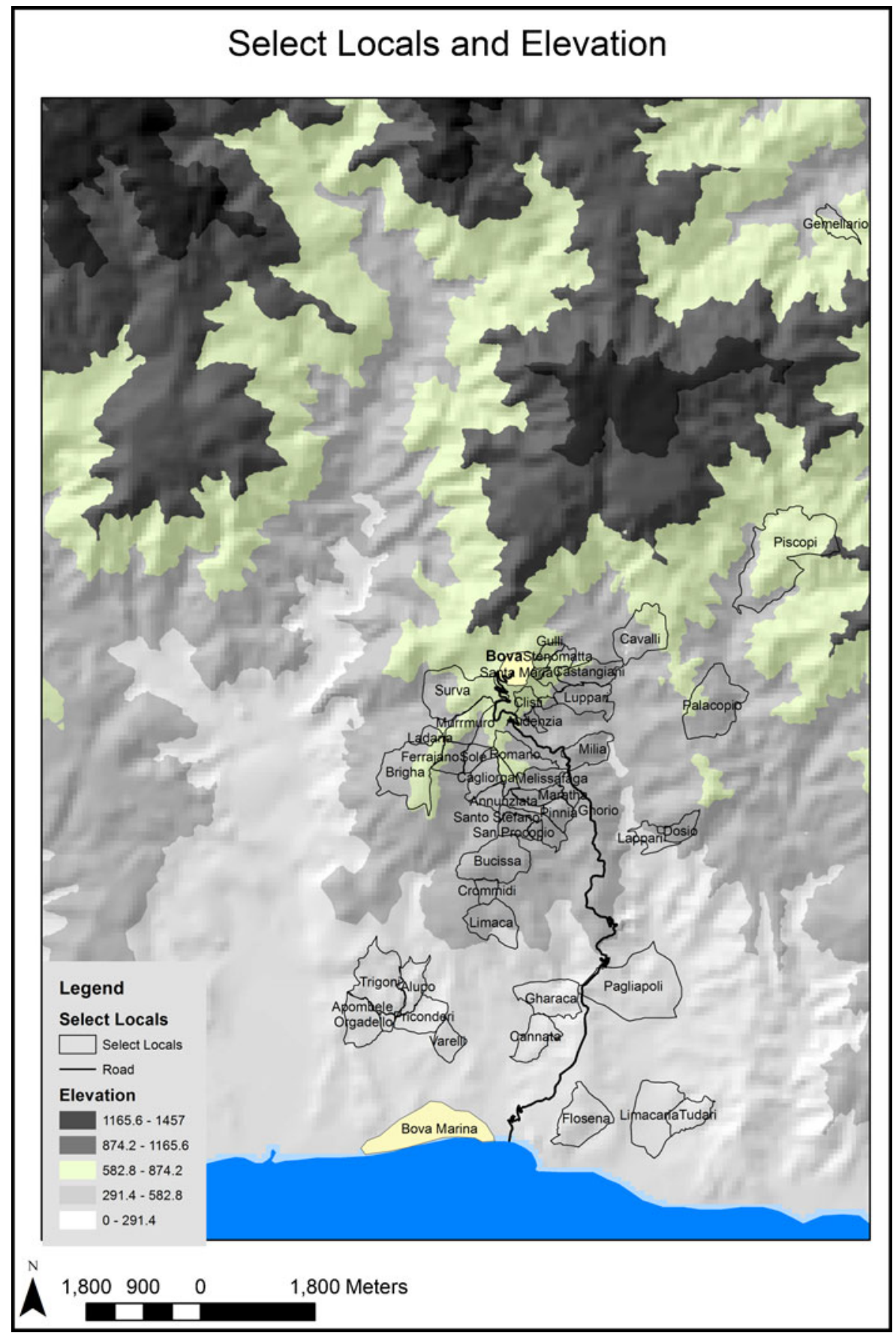

Fig. 4 Map with elevation and select study areas

locality in which it was located, the type/class of terrain, extent of the plot, and taxes owed based on the presumed return (Molinaro and Solimene 2006). By virtue of the 


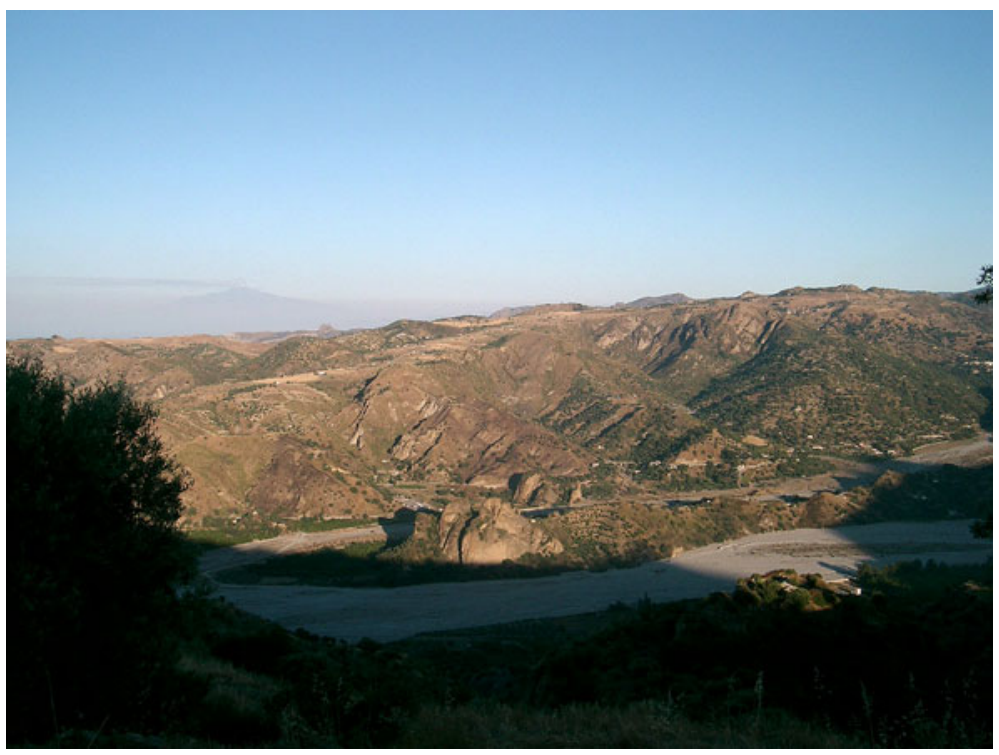

Fig. 5 View to South West with Etna in background, 2007

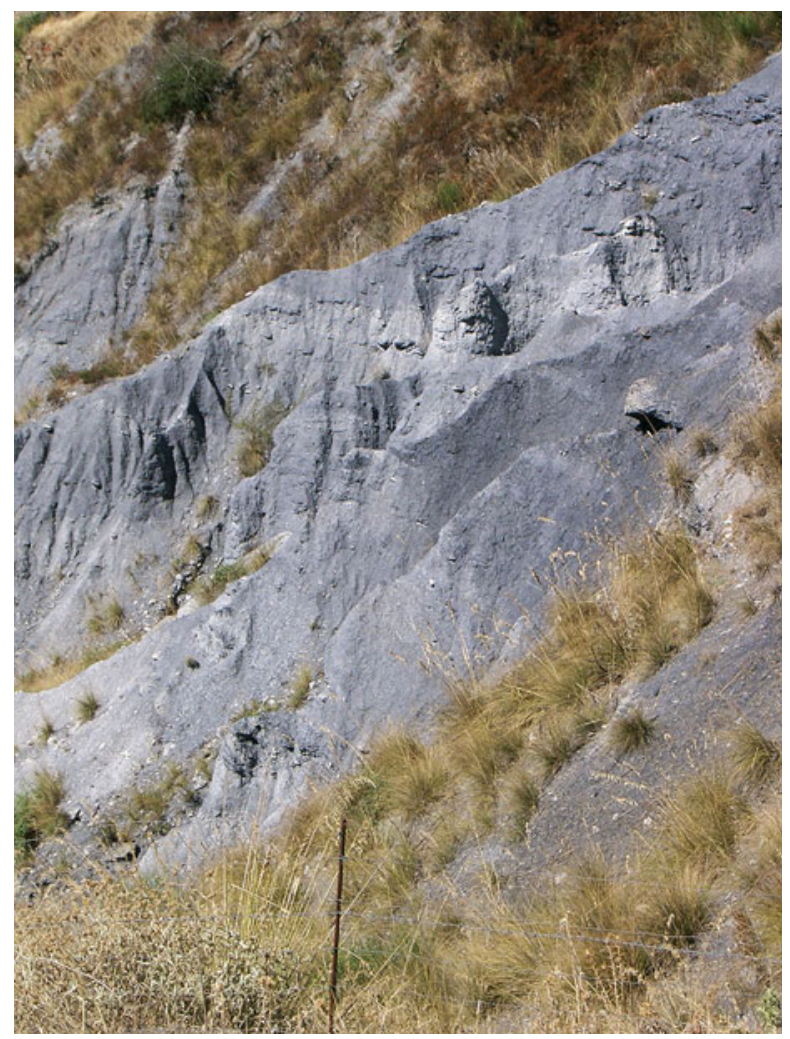

Fig. 6 View of eroding clays Fragiacomo 
system used to list individuals the document also provides information regarding occupations, civil status and familial relationships (C. ASRC 1807; Forbes 2007a; Lazrus 2005, 2006).

All information from the cadaster was entered into a database for analysis, comparison with field survey results, and GIS mapping. Verification of spatial information from the historical records was conducted in crews of two-three with the intention of corroborating the archival data and orienting ourselves on the ground with regard to the individual localities. It was possible in some cases to identify the remains of the types of features mentioned in the cadaster in the appropriate locals. Without parcel data (which I still hope to locate), it is only possible to connect the archival data with general locations that can be over $0.50 \mathrm{~km}$. Thus, for example, I can only say there is one casa matta (shack/shelter) listed for the locality of Melissofaga and that we were able to locate one structure there (Figs. 7 and 8). Whether it is the same one listed awaits further test excavations. We have no data from field survey that indicate that materials were collected from this site.

The Castato Murattiano was superseded by the Stato di Sezione in 1815. This was the document that was to be compiled based on the preliminary data collected by the 1807 cadaster (Molinaro and Solimene 2006). It standardizes the terms for crops and structures owned, and creates eight new taxable units called sections labeled A-H. Each

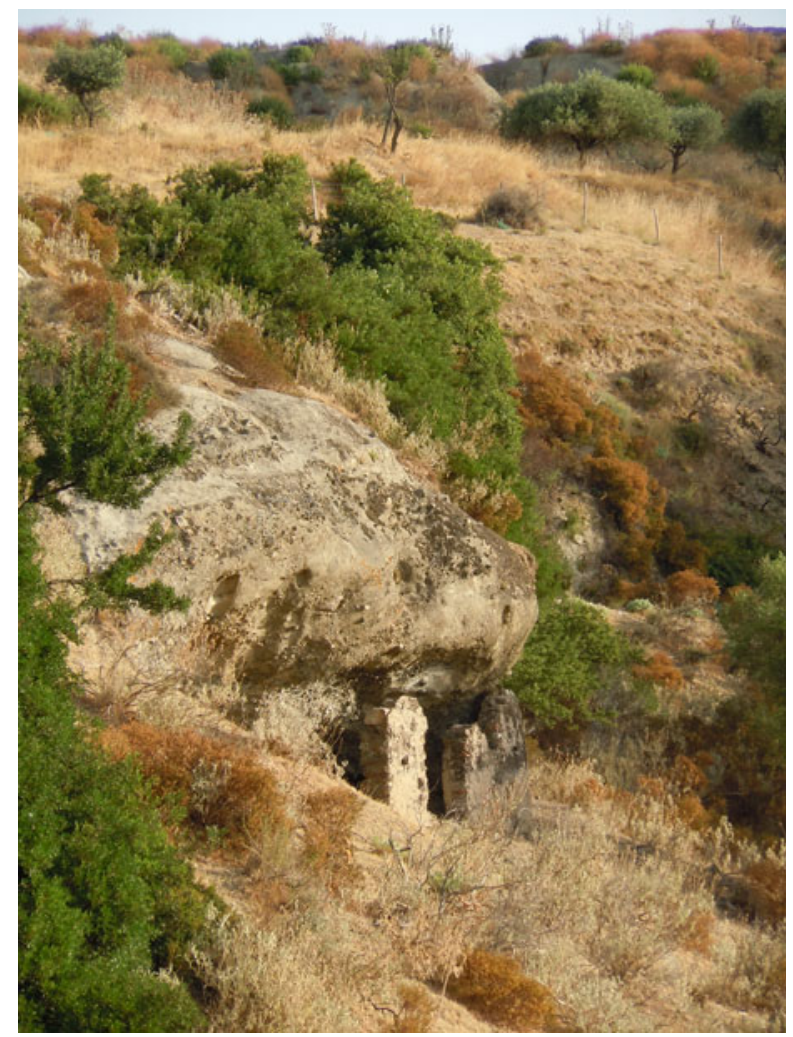

Fig. 7 Casa Matta, Melissofaga 2012 


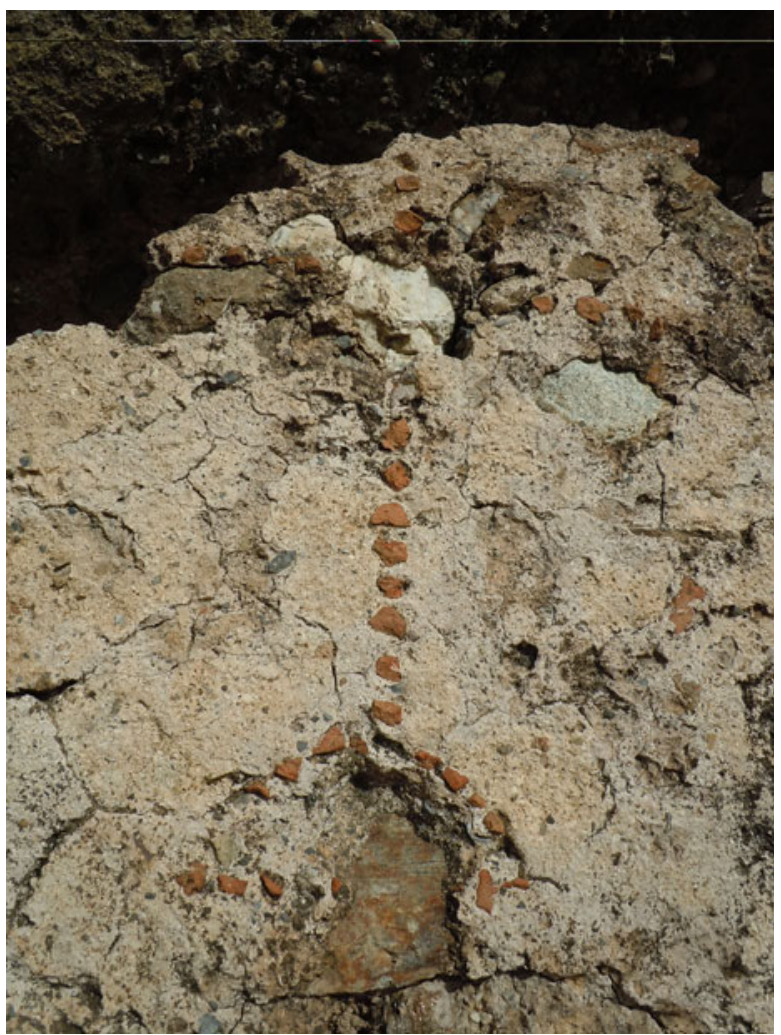

Fig. 8 Close up of cross on outer wall

section's geographic limits are recorded in a verbal description and the localities it encompassed are listed.

\section{Background Context}

Although it is generally recognized that landscapes are not static entities, the manner in which they are lived, utilized and altered shifts over time and with the viewer. Researchers investigating a particular region today are often challenged to consider the exploitation of, and movement through, a landscape that was vastly different from the one they actually encounter. Local inhabitants of different epochs and social classes may have perceived and defended their territories and resources differently from one another, and from those living in regional or imperial capitals located at a distance. These potentially different attitudes require us to consider the dynamics of the relationships between the inhabitants of this mountainous and ecologically diverse hinterland, in the late 1700s and early 1800s. Their relationships with the imperial government situated on the Campanian plain to the north; Naples under Bourbon or Napoleonic rule, or the regional capital of Reggio would surely be diverse (Rocheleau et al. 1995). 
While not densely populated today, there were fewer inhabitants living in Calabria Ultra during the 1700-1800s. The total population of the Kingdom of Naples in 1800 was 4,185,000 (Mitchell 2008). In the early 1780s the Abbe' di Saint-Non complained about the total lack of habitations encountered on his trip from Reggio to Locri (passing through Bova's territory). He noted that those he did meet had no food (de Saint Non 1978, p. 46). This did not change significantly even after the unification of Italy and was a cause of concern for various administrations in Naples and later those in the North who often blamed the undeveloped nature of the area on its lack of inhabitants. According to the papers of Domenico Alagna, a Bovan priest writing in 1744, transcribed by Pasquale Autilitano in 1862, there were 1,200 persons in the diocese of Bova in his day (Alagna 1744). According to the Catstato Murattiano there were 1,012 adults living in the municipality in 1807-08. Of course this document is a tax record not a census. Children and other non-tax payers are excluded. In 1881 there were 1,130 inhabitants (ASRC 1908; C. ASRC 1807). A population density of three-four people $/ \mathrm{km}^{2}$ can be calculated based on the 1744 or 1881 data (today it is 9.9) if the entire territory is included. More likely, however, would be a distribution where density was greatest in and near the town and thus the impact of humans on the landscape is dispersed in nature. Perhaps this accounts for the sparseness in archaeological artifacts from the post-medieval period. By current standards, people living in the Bovese at this time lived an isolated existence. Nonetheless this was a relatively important community, once a bishopric and thus a reputable center in this montane area and home to a respectable number of artisans and professionals.

Natural disasters, drought, and disease made life physically and economically unstable for inhabitants in Calabria Ultra, particularly after the catastrophic earthquake of 1783 when the Kingdom of Naples was under the rule of the Bourbon, Ferdinando IV. The earthquakes that hit Messina and Reggio in 1783 were particularly devastating and included multiple seismic events registering 7.3 and 8.1 Richter in the surrounding area (Postpichi 1985, pp. 56-60). These events had a major impact on the wider region. The earthquake pushed Naples to confiscate church lands, reorganize the south and send various commissions to assess its liability as it was concerned about the cost of the damages inflicted by the earthquake (Misafari 1973). It was an opportunity to address political, social and economic reforms, but one that was not seized to its fullest. The major reform that followed was the confiscation of church lands and the elimination of tax exemptions for the clergy, which in theory extended to the feudal landholders. In Bova's case these two were conflated as the town was a bishopric and the Archbishop of Reggio was the feudal landlord. The imperial initiatives were designed to create funds to address the catastrophe rather than to provide economic opportunity to a wider range of citizens. The result potentially favored a growing lower middle class by increasing private property ownership, especially after the official end of feudalism in the region in 1791. It might be expected that there would be archaeological evidence for this change in the form of improved field infrastructure or houses, roads, etc. According to the documents available however, the proposed reforms generally appeared to have favored those already in power, and whatever activities people were engaged in throughout the landscape does not seem to have left a vivid archaeological imprint or major shift in land use that we can recognize (de Filippis 1999; Guido 2002; Misafari 1973; Sirago 1997). 
Initially people were forbidden to leave the devastated area. Feudal lords were ordered to return to their properties to avoid their abandonment, clearly indicating that many important landowners were routinely absent from their lands and that the damage was severe enough to discourage reinvestment. Some of these individuals would have been renting out or otherwise working their lands through a variety of feudal contracts (Assante 1997). Others would simply have allowed the lands to remain in their natural state as an investment in the future for inheritance or as bargaining chips. Even today, buildings exist throughout the landscape in various states of repair or disintegration and quite a few seemingly "abandoned" structures have been turned into extremely comfortable homes and farmsteads since we began work in 1997. Money from the confiscated lands was eventually made available for the reconstruction of towers, mills and olive presses but none was made available to individuals to compensate for their losses giving local citizens another reason to distrust the imperial government (Boschi and Bordieri 1998, p. 108). The hardships endured by citizens in the region go beyond the catastrophe of a single earthquake. In the 3 years following the 1783 quake, there were five more earthquakes in the region that registered 7-8 on the Richter scale (Boschi and Bordieri 1998, pp. 106-7). This would have hampered any attempts at real economic recovery. By the Napoleonic period, the Kingdom of Naples was in turmoil due to the political uprisings of 1799 , responses to failed attempts at feudal and fiscal reforms. The Bourbon King, Ferdinand IV, was in exile in Sicily while Napoleon's brother Joseph and later Joachim Murat ruled from Naples introducing French reforms of the sort that Napoleon was implementing throughout the areas of Italy that he conquered (Di Scala 1995, p. 32).

The inhabitants of Bova were affected in two ways: first, with regard to local disturbances, evidence for collapsed structures, rock shelters, and landslides are evident in the landscape. However, it is not always possible to tie physical damage we see on the ground to a particular seismic event. The Neolithic materials from trench one were excavated in what remained of a collapsed rock shelter. The precise date of the collapse is unknown but it could have occurred in antiquity or as recently as 1978 (Boschi and Bordieri 1998; Foxhall 2006). The political and social effects of the disasters would have affected the inhabitants of Bova. Attempts to sell church lands left individuals uncertain if they would profit from any attempt to increase their personal ownership of land because the auction or direct sale prices of confiscated land were too high or because the perceived risks of full fiscal responsibility were too great (Assante 1997). In general, long term rentals remained critical to survival in this area well into the twentieth century so also did the rental and exchange of plots among local citizens with limited property ownership (Assante 1997; Autilitano nineteenth century).

When the Napoleonic regime established itself in Naples, reports on local conditions were required. Difficult travel conditions and limited access existed then and continued to be troublesome even at Unification (1861) when it was said that $90 \%$ of 412 Calabrian towns had no road infrastructure (Principe 1997, p. 190). This is certainly accurate for Bova, if we are referring to roads or paths that could handle a cart with a horse. There are, of course, many paths and trails radiating out from the town to the smaller communities in the area, to fields and the regional center in Reggio, but they were not well kept up, and we have not yet systematically investigated them as part of the project's field survey. Aside from the one main road there was nothing that connected the town with the coast. These paths would also have been used to take 
villagers to local sanctuaries and churches for feast and festivals binding the inhabitants together (Gibson 2007; Snead et al. 2009).

Despite the apparent need by Naples to redistribute funds from former church land sales as an aid to reconstruction efforts and to improve communications, the process proved long and elusive. Discerning the evidence for shifting ownership on the ground is challenging because most land was neither enclosed, nor personal property mapped. One might consider the earthquakes of the late 1700s as the defining moment in the development of southern Calabria from a social perspective, coloring the attitudes of the local population and those in other regions of Italy to this day. Local attitudes were influenced by the fact that aid for reconstruction was delayed nearly 10 years after the seismic events cited above (Boschi and Bordieri 1998, p. 31). This did not encourage collaboration with the new administration. Other areas of Italy developed at the expense of the Reggian region. Subsequent catastrophes such as the devastating earthquake of 1908 followed the same pattern (Boschi and Bordieri 1998).

\section{Post-Medieval Settlement}

Little or no mention is made of the ways in which the changes implemented by the Napoleonic government were received by lay and non-elite citizens. Most people in this area lived in small nucleated settlements like Bova with additional buildings scattered throughout the landscape (Arlacchi 1983; Ciaccio 1987, pp. 431, 436). People worked small fields in multiple localities with differing agricultural potential, not unlike citizens in the ancient Greek world or in Sardegna until recently (Foxhall 2000; Angioni 1982). Post-medieval Bovans appear to have exploited the uplands even more than the coast, perhaps due to the limited transportation infrastructure to the south. This continued to be the norm into the early twentieth century, as the roads that existed were still reported as impassable by wheeled vehicles (Principe 1997, p. 190). There are, however, hierarchies of road structures that are used by local inhabitants that may not directly benefit or be appreciated by outsiders, as is noted by Gibson regarding her work on Cyprus and Donnan on the Sinop Pennisula (Doonan et al. 2012; Gibson 2007). Bovans generally went to Reggio via the inland mule tracks; seven individuals are identified as mule drivers (C. ASRC 1807). In 1997 there was only one paved road linking the coast with Bova, in addition to a dirt track that often washed out or was impassible due to rock falls or deep gullies but utilized regularly by local inhabitants. That road has been surfaced and reinforced only in the last 7 years. Even so whole sections regularly wash out. This may be why there appears to be very little development of extended mercantile systems, as Arlacchi (1983) also notes for Cosenza, although there the density of settlement seems much greater than around Bova (see Fig. 4).

Our fieldwork reflects this picture. As mentioned above, there has been only one regularly tended (and in recent years paved) road connecting Bova with the coast at Bova Marina. There are, however, numerous paths and tracts utilized regularly by local inhabitants to travel to their fields and holdings, or to other inland towns. These have been used for many generations. We have also identified numerous structures in various states of (dis)repair as well as some evidence for mills, presses, and terraces. These features, plus the rarity of diagnostic post-medieval artifacts, (or our inability to recognize them), can lead to the conclusion that this area has been forsaken, yet this 
is clearly not an abandoned landscape (Figs. 9, 10, 11, 12 and 13). It is, rather, an extensively used and dynamic area that has been frequented since the Neolithic.

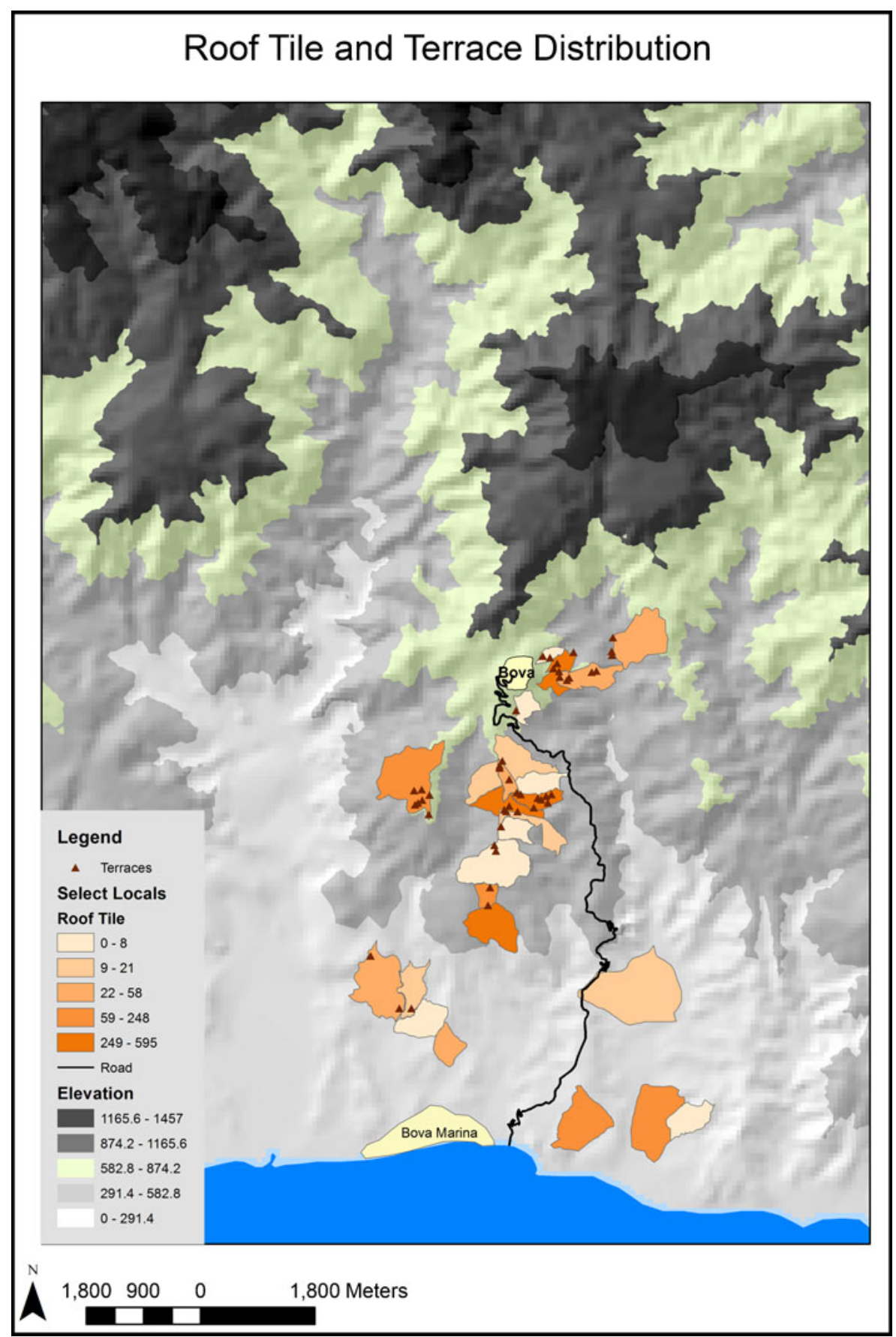

Fig. 9 Map of terraces and post-medieval artifacts 


\section{Finds and Structures Related to Agriculture}

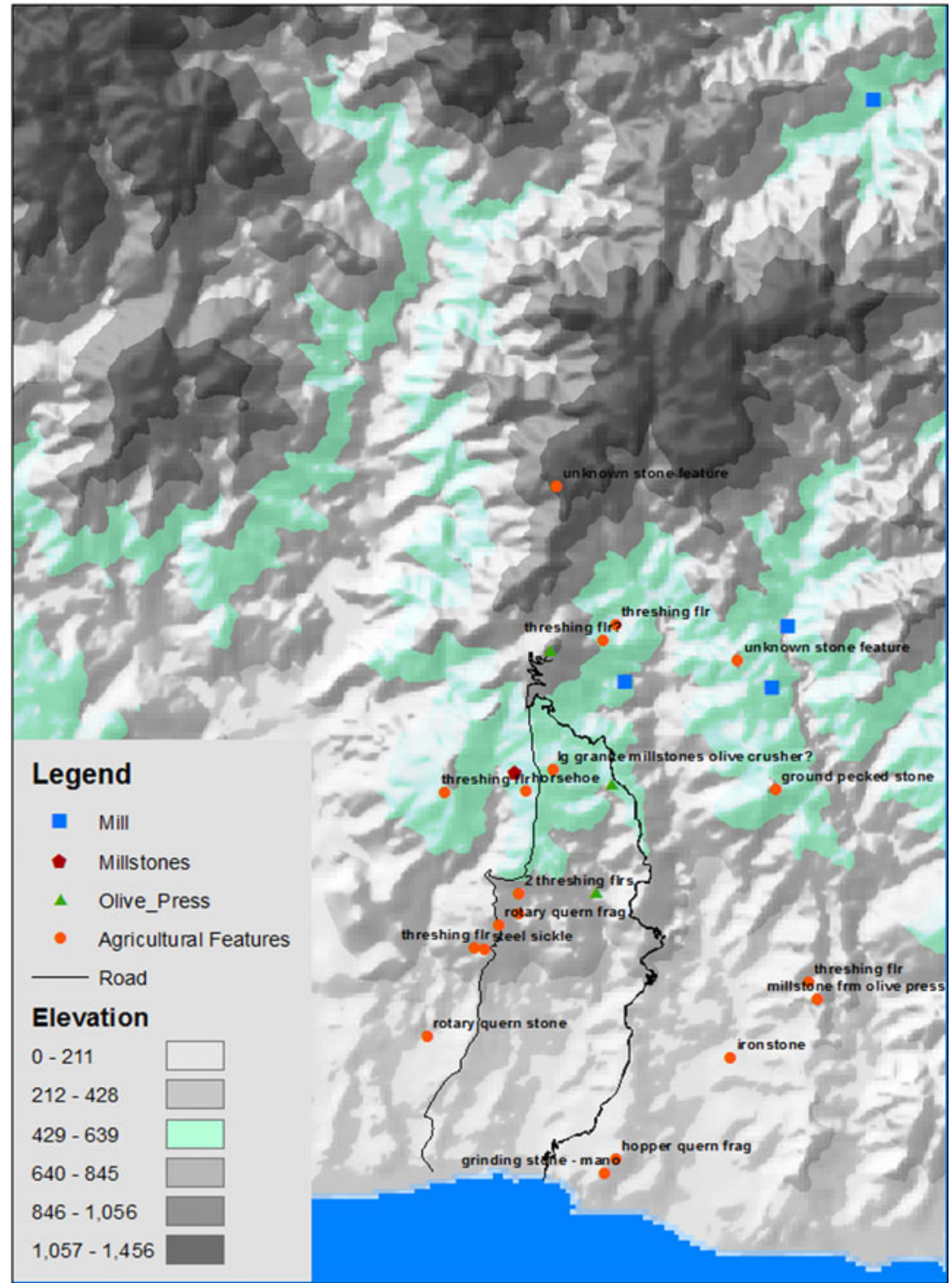

\section{A $1,7508750 \quad 1,750$ Meters}

Fig. 10 Map of agricultural finds

The lack of investment in the upkeep of rural buildings and fields from the postmedieval -contemporary periods provokes various interpretations. Generally those in the imperial administration (and later in the federal one) saw the conditions described as a sign of disinterested or lazy citizens, but one might also interpret it as representing a refusal to fully cooperate with shifting political regimes that routinely ignored the area. 


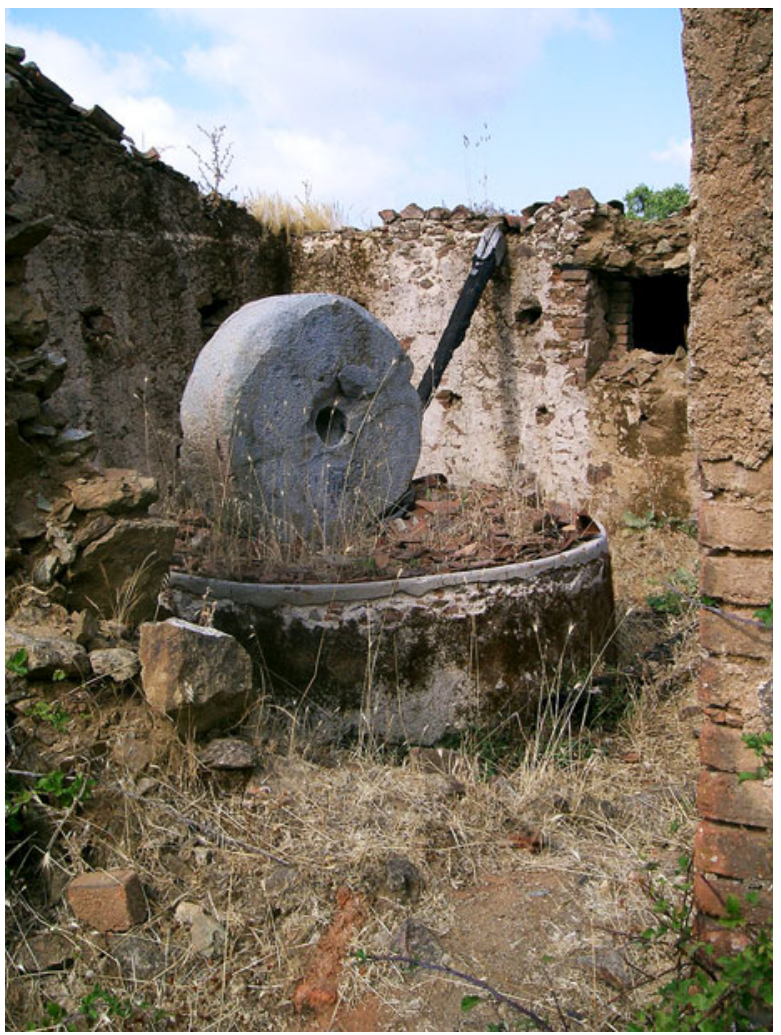

Fig. 11 Millstone, Cavalli

Alternatively, terrain derives value not only from its agricultural uses, but from its intrinsic worth. Inhabitants may elect to let fields return to a wild state, or rural buildings degrade, because of internal family politics, to avoid paying taxes, to pay fewer taxes, or as a result of personal/family/communal memories tied to a particular place. A family might live in northern Italy or abroad but retain property because it represents future capital for a still undefined need. Choices regarding working the land and the upkeep of structures reflect strategies concerning the potential for state money for repairs (or lack thereof) and planting of crops. Some holdings may also conserve landscapes of memory or of identity: places that people associate with individuals, personal or community events whether positive or negative (Botwick and McClane 2005; Branton 2009; Forbes 2007b; Given 2004; Rocheleau et al. 1995). In every instance the owners have made specific decisions to develop the land or not, regardless whether that decision reflects choices that outsiders might find profitable or beneficial.

Examination of four sample locales with archival data for rural homes that matched areas that we surveyed provides one potential link between datasets. One hundred eight houses were recorded on area forms and 182 rural houses are listed in the cadaster. Of the latter, 63 are located in areas that have been mapped (this number reflects only buildings specifically called "rural houses" or "shacks"). Unfortunately, it is still extremely difficult to correlate listed buildings with those we have located during survey, largely because we are unable to date the buildings that we have found. 


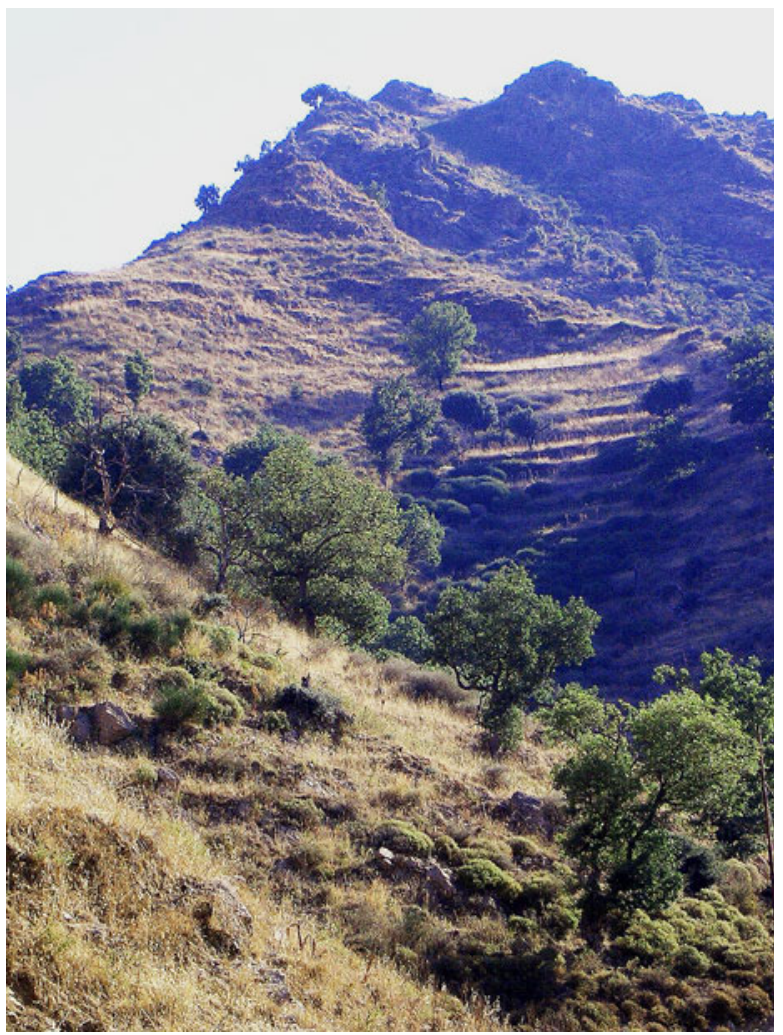

Fig. 12 Terraces, Clisti

Some may in fact date to the nineteenth century or earlier and have been abandoned or have been in intermittent use from the eighteenth century through to the twentieth century. Further chronological resolution is necessary to determine this (Fig. 14).

In Brigha, Melissofaga, Maratha and Cavalli, localities to the south SW and SE of Bova at roughly 463-713 m above sea level (asl) there are numerous structures. Six rural houses and one crumbling tower were listed for Brigha. We have identified at least six structures, possibly the remains of the tower and two threshing floors through field survey. In 1807 one house in this local was claimed by a day laborer; the others were owned by wealthy citizens. A lawyer listed three houses plus the tower. There are two homes listed in the cadaster in the locality of Melissofaga, both owned by a person without any listed profession. One house is listed as a rural house, the other as a casa matta, a more improvised shelter or shack. During our explorations of the locale to corroborate the archival materials we may have identified a clear candidate for that home, and I plan to follow up with excavation in the future (see Figs. 7 and 8). In Maratha, the cadaster lists only one home, the property of a teacher. The BMAP survey identified five structures mostly likely of a later date, but whether of the later 1800s or all from the twentieth century is unclear. Two of those houses appear to potentially belong to the nineteenth century (Figs. 15 and 16). Finally, in the area of Cavalli the cadaster lists 21 buildings ranging from a multistory home to rural houses and shelters. The multistory home is owned by an affluent citizen. Forbes's 2005-06 work in this 


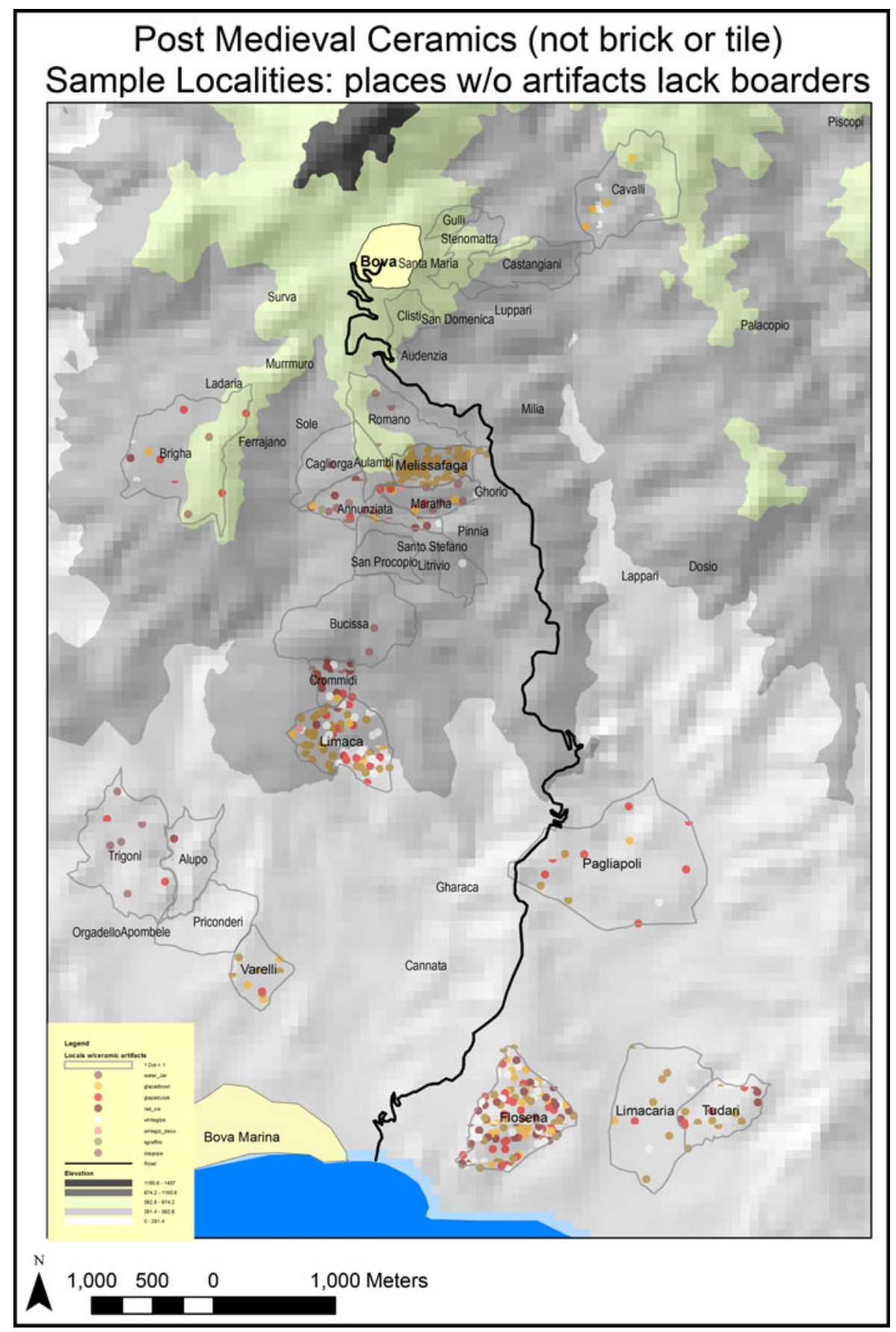

Fig. 13 Post-medieval ceramics

area suggested that there were post-medieval structures in the area. He investigated a two-story structure constructed with the lower level for animals and storage and living 


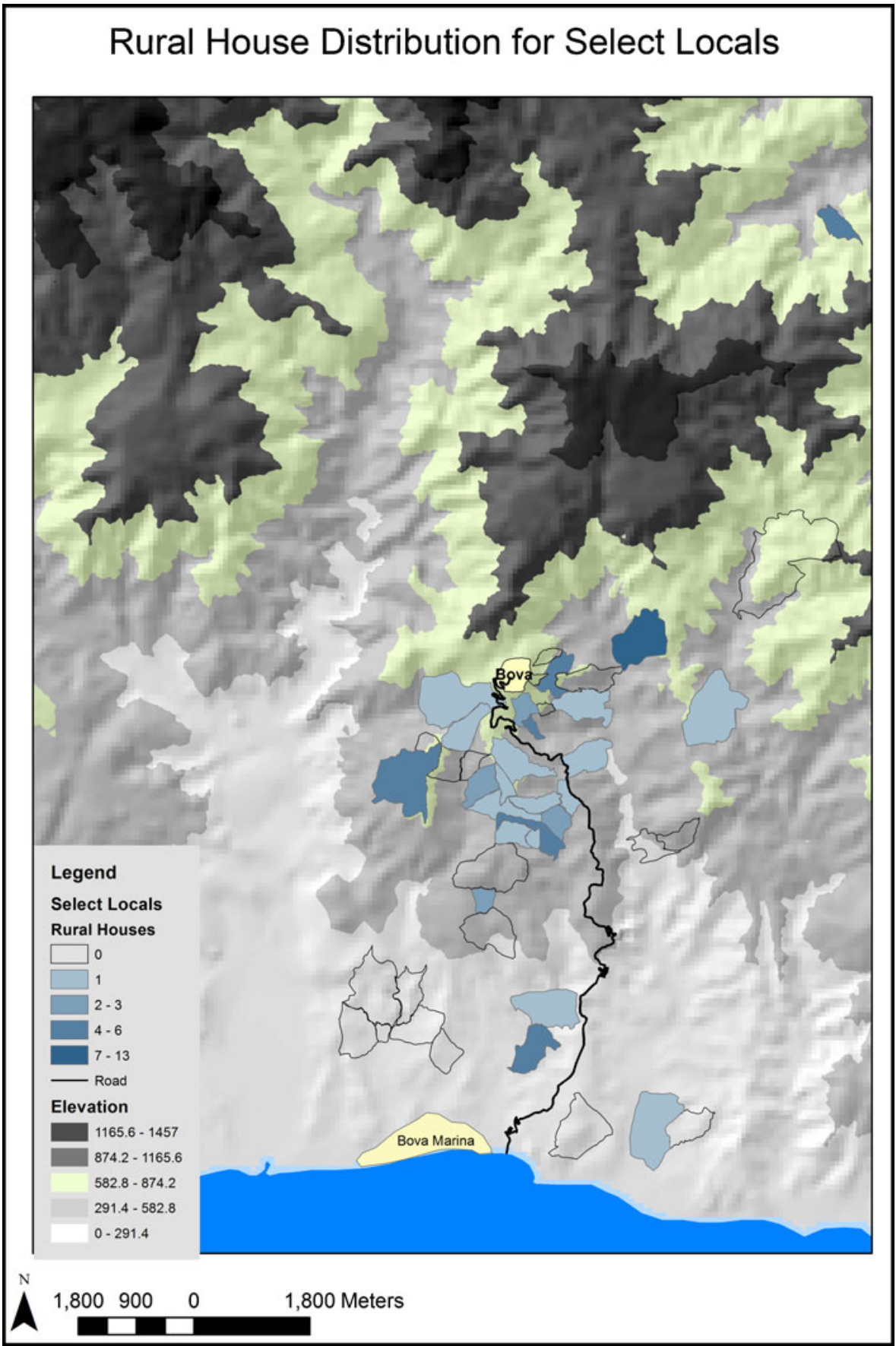

Fig. 14 Rural house distribution for selected areas

quarters above, a typical arrangement (Fig. 17) (Ciaccio 1987; Forbes 2006; Manzi and Ruggiero 1987). There are many structures in the landscape in various stages of 


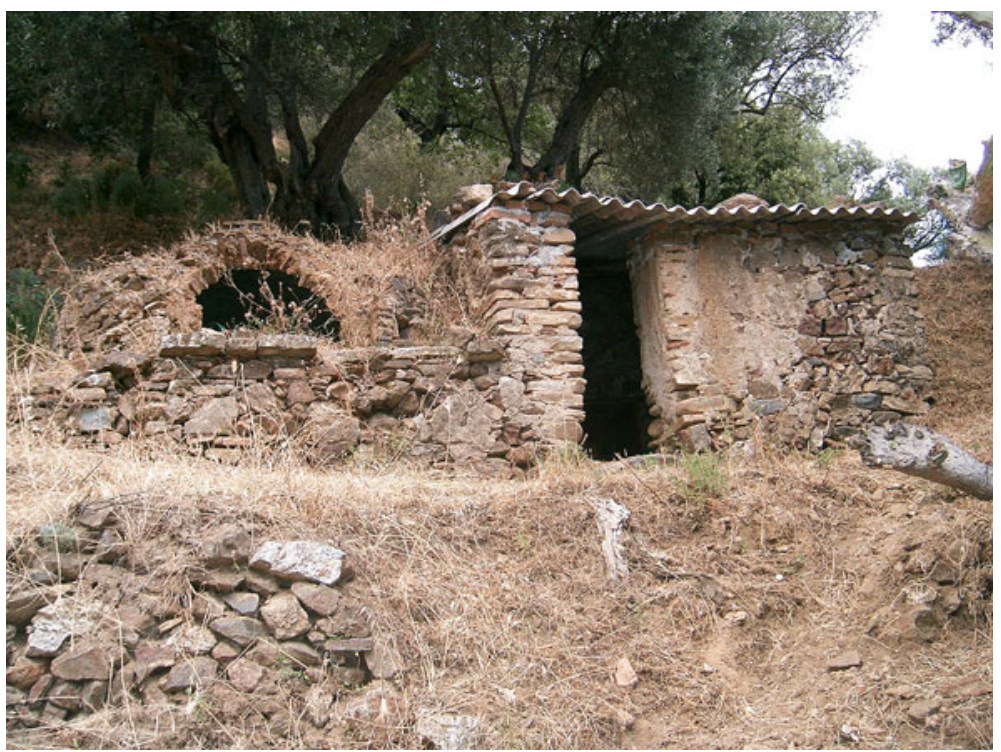

Fig. 15 Rural House, Maratha 2007

degradation that are not in fact abandoned in the usual sense, but are currently unused, or repurposed. Aside from temporal disparities among the residential structures, it is worth remembering that because we lack a clear chronological typology for these structures, we do not know how many were occupied contemporaneously. I hope to address this issue with future fieldwork.

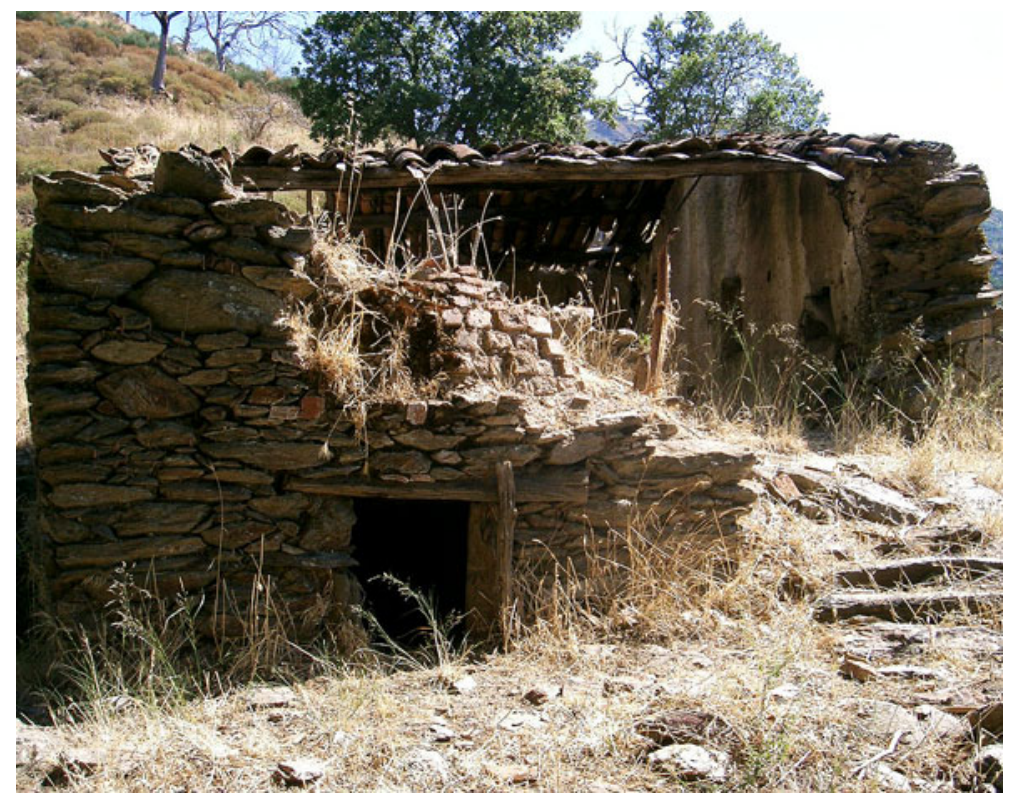

Fig. 16 Rural House, Cavalli 2006 


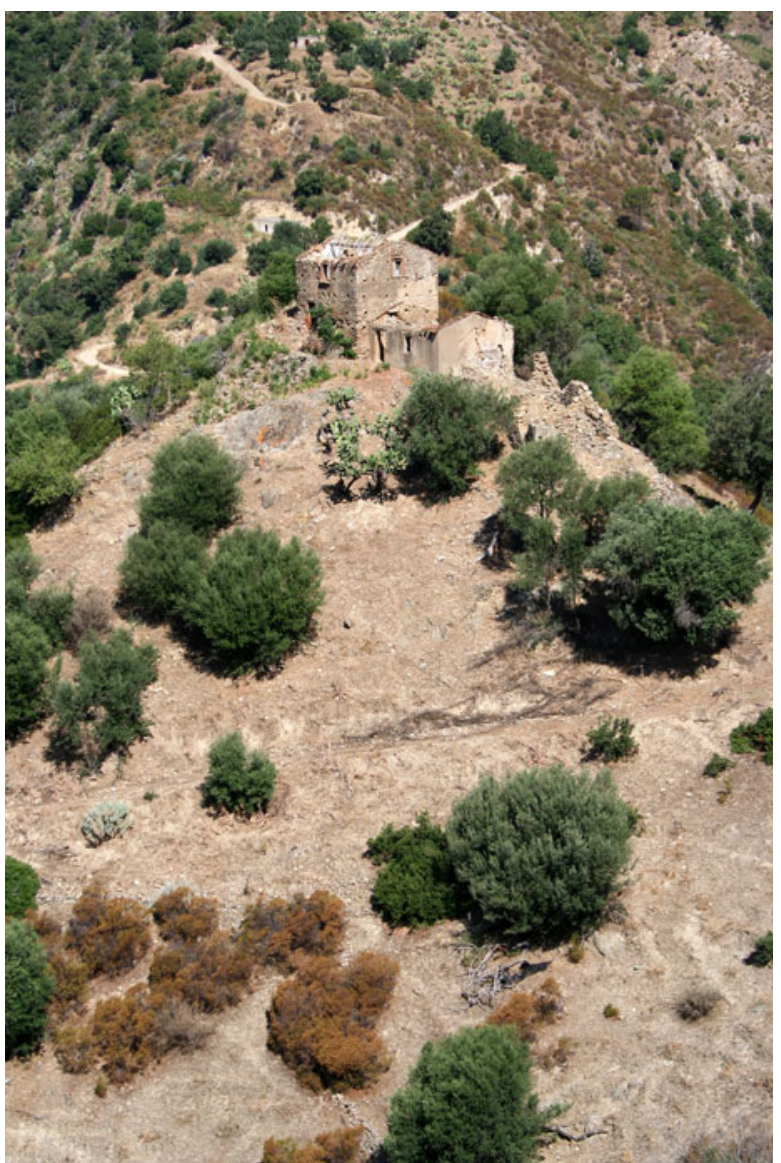

Fig. 17 Rural two story house, Paracopio (photo by H. Forbes)

The landscape which hosts these structures has changed significantly since the 1700 s and 1800s. The terrain, mostly undulating, is locally highly degraded with little stable soil, particularly seaward. There are however, remnants of forest (particularly in the areas to the north and northeast of town) and some new reforestation mostly on the plateau northeast of town. It is a resilient landscape. We have witnessed rapid recovery after fire and blossoming of plants after more consistent periods of rain. The zones at $400 \mathrm{~m}$ and above once included trees we no longer find there such as: myrtle, mastic, tree heather, willow, broom, and laurel. There were also more oaks and chestnuts mentioned in the records than are evident today. At higher elevations the archival documents describe extended areas of oak (Quercus robur and Q. ilex), beech, cedar, chestnut, hazel, alder, and columbine. Most of the early travelers remark on the densely wooded environment, noting the difficulties in traversing it (Alagna 1744; Autilitano nineteenth century; Galanti 1806; Lear 2003). During the 1820s-30s records attesting to an increase in the exploitation of the forested regions appear. They mark the transformation from a more wooded and ecologically diverse habitat to the one that we are familiar with today. Today, while there are some oaks and chestnuts and the occasional cedar, most of the vegetation described is gone, replaced by cultivated and 
imported plants or greatly denuded surfaces. References to the oak and beech forests continue into the 1840s (ASRC 1832a, 1842a). Maritime and other pines and eucalyptus reflect recent planting (Lazrus and Robb 1998; Pasquale 1863). Some of the current deforestation may date as late as 1902, when it was reported that many chestnuts, some "hundreds of years old" were being cut down to support tannin factories near Cosenza and Catanzaro (Taruffi et al. 1908). The trees generally covered the steeper sides of slopes. Their removal accelerated erosion in those areas making subsequent reforestation more difficult, exacerbating conflicts among poorer citizens, professionals, the church and the municipality and potentially affecting the distribution/survival of archaeological artifacts (Alagna 1744, p. 58; Taruffi et al. 1908). In the early/mid 1800 s references to the utilization of forested areas belonging to the municipality for planting and grazing include some of the earliest references to abuses of grazing in those areas (ASRC 1832a). The abuses coincide with the transition from ecclesiastical to municipal control of various upland activities (ASRC 1842b). Poorer citizens denounce the larger entities for using accusations of abuse to take more land to sell for their own profit.

\section{Perceptions and Pressures from Near and Far}

In the late 1700-1800s Calabria Ultra was generally perceived by those in the capital, Naples (and later by twentieth-century scholars), as an economically depressed region. In 1796, $77 \%$ of Southern Calabrians lived on feudal or state/municipal land even though more than 10 years had passed since the decrees which followed the earthquake of 1783 (Sirago 1997, p. 276).

The scarcity of citizens in Calabria Ultra was generally perceived by those in the northern reaches of the Kingdom of Naples as contributing to the underdeveloped nature of the region, providing impetus for development initiatives that were not necessarily well received locally (Caldora 1960; Ciaccio 1987, pp. 427-446; Gatto 1994; Principe 1997, pp. 187-205). Tax evasion was rampant in Calabria Ultra in the late 1700s. Cardinal Ruffo attempted to rectify the problem by reducing the "head" and "labor" taxes by half (Rao 1992, p. 326). The Napoleonic regime attempted to remedy the problem by taxing products rather than individuals. This decision provides a window into how the land was used during this period. The tax documents were compiled in the individual communities by a committee that consisted of representatives from each class of citizens who acted as a council receiving and reviewing the submissions (ASN 1742; C. ASRC 1807). The system was open to abuses, but it was also subject to a certain control in the form of peer pressure. It took so long to submit the Catasto Murattiano and the follow up Stato di Sezione that there was a new regime in power. It is possible that this set of taxes were never collected strengthening this form of community resistance.

The cadaster indicates that in the early 1800 s the church, two lawyers and a doctor still owned the most land. It is, however, possible that poor citizens, some of whom were tenant farmers and others who were day laborers, may have felt a sense of ownership of the land they worked for others. The turn of the nineteenth century was a period of diminished guidance for Bova's community as no bishop had been appointed since 1793 owing to internal ecclesiastical politics. This lack of 
administration at a moment of shifting property ownership and imperial control led to looser oversight of ecclesiastically controlled lands, leaving the municipality and local citizens feeling empowered and less liable for payments on land they used. Perhaps citizens felt as if the land had become theirs by default, leading to the various lawsuits of the era. That said, as late as 1856 the Church continued to purchase new land in the municipality and it maintained its role as an important political, economic and social player (Johnson 2007; LaCava 2001). This would have given Bova's elite (often clergy members or their relatives) important economic and political ties not only to their local church but to the bishopric in Reggio and thus to the imperial court. It is not clear at this stage of my research what the church's role as power broker looks like archaeologically. With a deeper understanding of the artifacts recovered we should be able to distinguish which materials were favored by the elite, whether they had more presence outside of town, or virtually none beyond the town, or we may find that social status is not as bound to material goods here as elsewhere. Perhaps here, where you own land or the type of land you own is the important marker of status. The church does appear to own the most easily cultivated lands, those closest to town as well as the greatest number of plots within easy reach of the road.

Textual records of the period indicate that gardens were common, as were vineyards, extensive use of grain and cultivation of mulberries largely for export (Rao 1992, p. 350). We have found few mulberry trees still standing within our survey area, and rural gardens. The flotation samples from the excavations were taken from the prehistoric and classical period levels. There were 69 plots with mulberries recorded in the cadaster. Lawyer Domenico Nesci owned the largest total area dedicated to them at 3.98 ha (the next largest holdings are by the area's other two wealthiest men, a doctor and a lawyer with 0.94 and 0.69 ha a piece). While none of these holdings are very large, these men must have been supplying most of the cocoons for the two local silk presses (C. ASRC 1807), both located within the town.

Sent to report on the consequences of the 1783 earthquake for the Bourbon government in Naples, Domenico Grimaldi, the Marchese of Seminara, educated in Naples and Switzerland, became an administrator for the crown. He took the opportunity to show his "northern superiority and knowledge" by roundly criticizing the citizens for using the hoe, and not "properly" fertilizing or tending to their crops (Gatto 1994). Were the methods employed by Bovans inadequate, or were they more appropriate to the climate, soils and general economy of their territory rather than Switzerland, where he was trained?

Giuseppe Pasquale, an administrator sent in 1863 by the government of the newly unified nation, produced a detailed report. His work reflects the typical habits of administrations assessing newly acquired territory and attempting to certify that all due revenues are collected (Given 2004). He noted that plots were often too small and too steep to make profitable use of oxen. The animals were costly to maintain. He could not envision a way for famers to shift to a plough-based system (Pasquale 1863, p. 117; Rao 1992, p. 332). Pasquale was also surprised that trees were often planted close together, an uncommon practice elsewhere that he believed reflected the farmers' desire to increase fruit production and to "contribute to the production of lower soil layers" (Pasquale 1863, p. 104). While he did not approve of the practices observed, he acknowledged that the local inhabitants understood best how to promote agriculture and to maintain the soil of land they had worked for generations. 
Pasquale was quite specific in his criticisms considering the use of internal hedges (mostly prickly pear based on cadastral and field records). He considered them a terrible waste because they utilized valuable land that in his opinion should have be dedicated to cultivation (Pasquale 1863; Taruffi et al. 1908). However, prickly pears were probably valued for their multiple uses: they attract the cochineal beetle used for red dye, the fruit is edible and can be dried for use throughout the year, the paddles become summer fodder and they act as boundary markers (Taruffi et al. 1908). They continue to be used in the same fashion today. Interestingly, the church does not claim any prickly pear as part of its holdings. Pasquale's general observations are supported by the analysis of the cadastral data but also reinforce the fact that most individuals were planting in a manner that demonstrates their keen sense of the local conditions and risks.

Are the issues raised by these two administrators a question of perspective, of class, or fact? At a distance, it may be difficult to come to a satisfactory answer, but the impressions that northern Italians have of their contemporaries in the south have not changed significantly in nature over the centuries. Many northern schemes to improve the south have failed due to basic miscalculations concerning what the local environment could support, in addition to the problem of unreliable funding. This latter issue may have been responsible for opening the way to later fiscal irregularities and the rise of organized crime in the south. Those activities are however, more likely to find their foundation in the failed attempts to establish a republic in the south after the organizational failures following the 1783 earthquake (Di Scala 1995, p. 32).

\section{Uses of the Land}

Considering the number of plots owned, land/tax data from the Catasto Murattiano initially appeared to indicate that taxed property was rather evenly divided among stakeholders. Further analysis illustrates that in terms of hectares, the church and clergy still possessed the vast majority of the land, reinforcing the notion that the shift from feudal holdings to individual holdings largely benefited the same individuals without significantly enlarging the tax base. Tracking individual plots on the ground archaeologically is challenging, as individual fields were rarely delineated with walls, bramble and prickly pear being the preferred materials. I have not located parcel maps for the period in any of the Reggian or local archives. Even when we identify older terraces, they are rarely sustained by stone walls which might conserve artifacts (see Fig. 12). Additionally, surface erosion has significantly altered the surfaces surveyed (Fig. 18, also see Fig. 6). It is possible, however, to identify traces of terraces in many localities. We have evidence for post-medieval materials in conjunction with 85 areas where there are the remains of terraces (of a total of 126 areas with terraces). One hundred five areas have terraces and some kind of post-medieval materials. Of these, 29 coincide with localities that I have currently mapped (see Figs. 9, 10, and 13). Threshing floors and individual querns are mostly found in the mid highlands between 500 and 1,000 m asl, while the land with the most grain is found below $500 \mathrm{~m}$ asl.

Ecclesiastical and municipal holdings are larger than those of other individuals, including artisans and professionals. Small plot sizes are consistent with Pasquale's 1863 assessment. He noted that most land holdings were in the 2-3 hectare range (Pasquale 1863, p. 104). The larger ones are likely to be planted or covered in trees (oak 


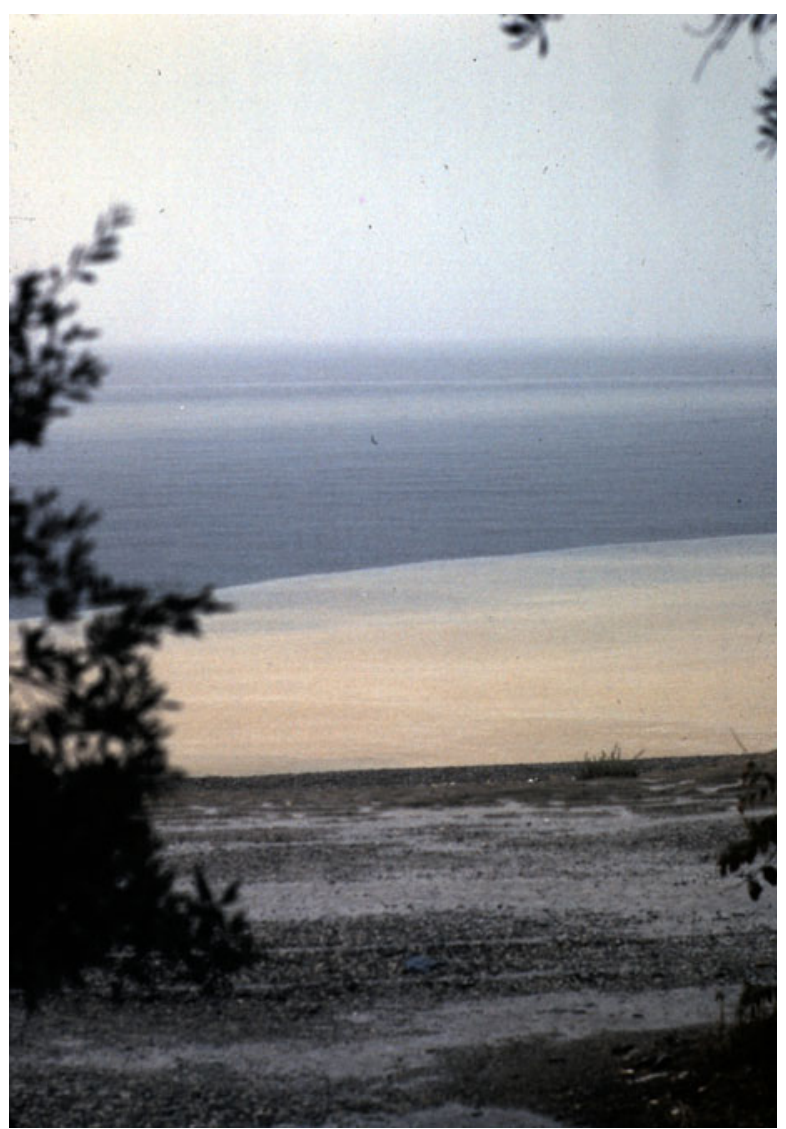

Fig. 18 Soil washing out to sea after brief intense rain, October 1999

or chestnut, or sometimes fruit and nut). Bizzocchi, however, mentions that taking into account crop rotation, a family of five needs about 10 ha devoted to wheat to produce enough grain in a rain-fed regime (Bizzocchi 2009, p. 28). Aside from the church and clergy, only three individuals have a total of 10 or more hectares of grain, albeit distributed across multiple localities. Data from the Catasto Murattiano indicate that most Bovans owned or worked numerous plots of up to a half hectare across multiple localities. Only the church, individual clergy and the municipality itself own plots that are one hectare or larger (C. ASRC 1807). Sample contemporary field sizes calculated in GIS using aerial photographs from the 1990s and on the ground survey indicate that most plots are still well under one hectare in size. This differs in many respects from the distribution of land around Cosenza and Locorotondo, where large landholdings are common (Arlacchi 1983; Galt 1991). Some individual clergy own large plots of sterile or otherwise unproductive land (fallow, too steep or poor quality soil although these terms are clearly subjective) or land strategically claimed as such. This designation in the records may represent a deliberate form of non-cooperation with the government by clergy and others.

Generally, grazing was loosely regulated and often mixed with areas of cultivation, as is common elsewhere in the Mediterranean (Given 2004). Pigs and ovines were left 
largely on their own to graze in the forested zones or in areas where chestnut and oak trees were abundant (mostly in mid altitudes and upper elevations). This elastic structure represents a good risk management strategy (Given 2004). Many large tracts of forested or undomesticated land were still in the hands of the church or were the property of the municipality both before and after the brief period of Napoleonic rule (S. ASRC 1822; ASRC 1832b) (Table 1).

The size of the plots and the distribution of plant types seem to reflect practices that go back perhaps as far as the 1500s (Caridi 1997, p. 228), (Fig. 19). This mix of crops was not necessarily deemed economically productive by the administration in Naples, but clearly inhabitants thought it was a productive strategy. The lack of adequate roads would have increased the price of moving many products out of the hills. Pasquale notes that olives, mulberries and citrus were largely grown for export purposes "at the expense of grain for personal use" (Pasquale 1863). Yet, there are only two plots of citrus registered; they belonged to the Bovan Bishop's refectory. Given the lack of roads connecting Bova and its territory to the coast, the question is: who were their external trade markets/partners? Was it the provincial capital of Reggio and beyond, or a more localized exchange with neighboring hill towns? Palizzi and Gerace were both formally under tight feudal control of a single family. Locri is farther afield. Westward however, was Melito Porto Salvo where shipments could be made by small sailing vessels. Was this a more profitable alternative?

Olives and mulberries were grown in the uplands and likely moved to market along internal mule tracks. Plenty of these tracks or their remains still exist within Bova's territory. This might reflect a desire to get rich quick by growing cash crops. Pasquale may have been evaluating agricultural choices from the viewpoint of the outside economy rather than the local one, where most plots were kept under the size limit that required cash payment. Grain was often used as the method of payment, a practice that reaches back to at least the 1600s (as was the case with other products such as olives, olive oil or mulberry branches) (Caridi 1997, p. 229). In kind payment is one indicator of the general level of poverty. It might also reflect the desire of inhabitants to avoid growing crops whose revenues would be taken by government payments. It was common for local transactions (especially purchase and rent of lands) to be kept deliberately under the threshold that would require payment in cash rather than kind (ASN 1742; ASRC 1826).

There are fewer localities under 200 masl listed in the Catasto Murattiano that are currently identifiable. Where they exist the land is almost exclusively in the hands of the church or wealthier landowners. Day laborers are listed for the land they worked, whether

Table 1 Total hectares owned based on entries to the Catasto Murattiano

\begin{tabular}{lcc}
\hline Owner & Total hectares & Average plot size \\
\hline Church (as organization) & 1243.249 & 3.42 \\
Municipality & 126.274 & 1.23 \\
Church (individuals) & 514.53 & 2.81 \\
All Non Ecclesiastical Citizens & 1101.79 & 0.40 \\
All Non-Professional citizens & 637.33 & 0.36 \\
Three Largest Landholders & 135.592 & 0.56 \\
\hline
\end{tabular}




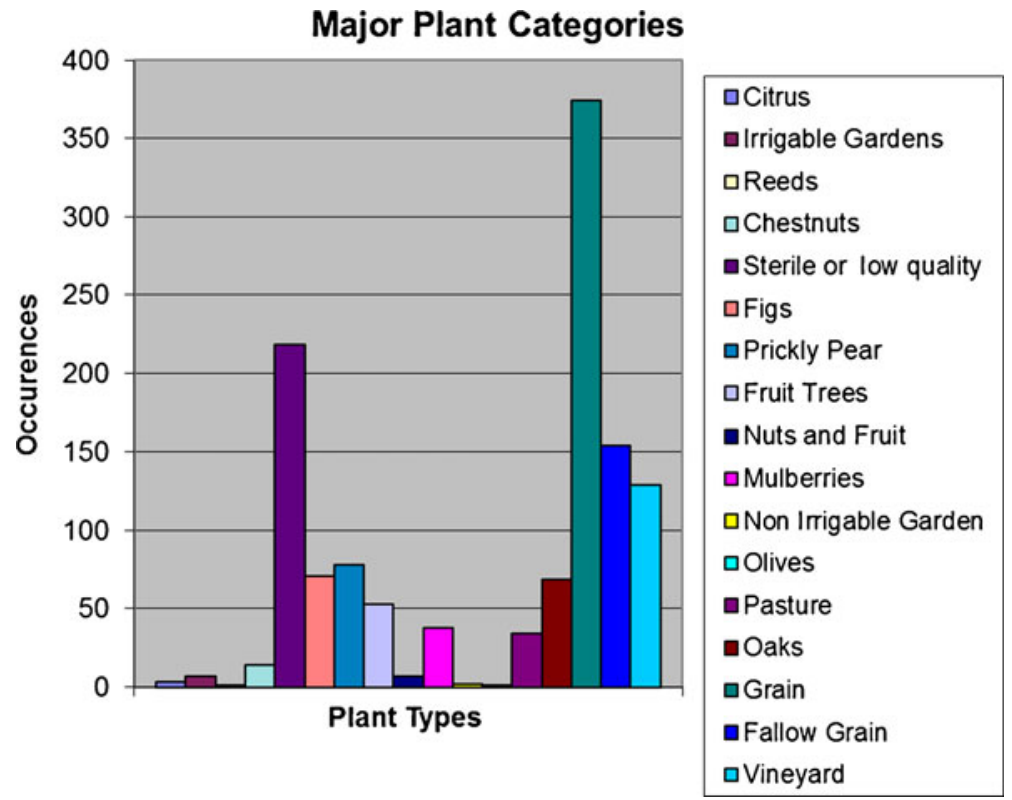

Fig. 19 Principal plant categories

it was owned by the church or wealthier individuals. Farmers may or may not be in contractual relationships. The lowland areas produce grain, small quantities of mulberries, figs or are declared sterile. The plots, despite being easier to sow, are however no larger than elsewhere. Today they are those most affected by urbanization and industrialization. Of the localities listed in the records that were exploited and that can be identified, many are to be found at altitudes between 300 and 600 masl or else in the mountainous areas between Bova and Africo or Bova and Palizzi (between 600 and 2,240 masl). Artifacts from the survey data appear to corroborate this land-use with threshing floors and mill stones found in some localities (see Fig. 10). Not surprisingly, these areas were also closer to town, although the steepness of the terrain would have made the journey to one's field fairly arduous, especially with harvested crops or heavier supplies.

Whether the difficulty in completing the Catasto Murattiano was due to intransigency on the part of the local municipality, the individual citizens or the bureaucracy is difficult to determine. It would not, however, be unreasonable to assume that Bovan citizens played their part in resisting this latest imposition by procrastinating and providing vague responses; especially given their experiences after the earthquakes of the 1780s and their history of independent actions (such as resisting the order to switch to the Latin rite). That event dates to the 1400s. The Bishop of Bova in that period joined other Calabrian churches in recognizing the Patriarch of Constantinople over the Pope (Russo 1961, p. 165,175). In the late 1400s all churches using the Greek rite were ordered to cease the practice. In defiance of Church authorities in Reggio and Rome, Bova continued to maintain the Greek rite for another 100 years until 1570 (Given 2004; Russo 1961, p. 354). Perhaps this liturgical revolt combined with relative isolation produced a confidence that influenced their approach to future Spanish and French rules and even to the period of Italian rule both at unification and beyond (Misafari 1973; Rao 1992, p. 332; Russo 1961). 
The importance and reach of the church within Bova's community likely contributed to difficulties in reapportioning lands that were once under church control. Important social structures, such as loan associations, savings associations and the seminaries, were not only intertwined with the community's cultural, economic and political functions but with familial relationships as well. The loan association in particular, founded by Stefano Morabito, Bishop of Bova (1752-64) functioned as a pawn shop receiving personal items ranging from copper cooking pots to pieces of silk as collateral for loans to pay rent, taxes or purchase seeds (Ferrante 1993). Many of the items brought in as collateral for loans were of the most basic and fundamental utility in daily life (bedsteads and cooking pots, for example) pointing to the economic burdens that many Bovans bore (Ferrante 1993). Any tensions that might exist between the local churchmen and the former feudal owner, the Archbishop of Reggio, are less obvious. In examining commentaries and tax records the church continued to be a major territorial stakeholder in the municipality insofar as its administrative, training and philanthropic divisions, as well as its individual clergy, still owned much of land decades after the reforms of the $1780 \mathrm{~s}-90 \mathrm{~s}$. Identifying church holdings through the survey materials covered is not currently possible, but this work provides a strong foundation for future analysis of these materials. The church, the municipality and two of the major landholders have the only records from the Napoleonic cadaster that get rectified downward and that had to have been approved by the whole committee. Perhaps the others thought that by approving the revision they might have collateral for negotiations in the future.

Difficult access may be key in making Bova appear of marginal importance to those in the capital. Perhaps the local inhabitants preferred it that way. By concentrating on exploiting goods locally and keeping transportation infrastructure limited they may have been trying to balance exploitation of forest and agricultural resources for local use against what they might have gained with a greater connection to the wider economy. This would effectively keep the majority of Bovans away from the attention of nosy tax collectors and others from the capital looking to exploit the region and its inhabitants.

\section{Conclusions}

The broad examination of data from the Catasto Murattiano and the BMAP field survey analyzed so far indicates that despite any and all attempts at real change, Bova at the turn of the nineteenth century was still dominated by the church. That said, since no one owned large estates, the fractured land use patterns continued to apply. In the field, there is little evidence from the post-medieval period of any single large scale landholding or construction. Whatever evidence we have of terracing from the period, remains of houses or industrial structures points to an extensive use of the land with small scattered or clustered plots thus corroborating the cadastral data.

The lack of governmental investments in a region afflicted by one or more major earthquake per generation sent a strong signal that it was futile to develop the region, then or now. Frequent epidemics and pests may have contributed to a weakened local will to protect forest resources when the church or municipality had the opportunity to raise funds by selling them off. While the church continued to be the dominant player in the area, artisans and professionals in Bova were working to maintain or increase their land holdings with only limited results. Even the wealthiest of Bovans seems to have 
been living in impoverished circumstances. This is surely supported by the paucity of material goods from this period. The lack of general prosperity is one of the clearest messages we can take from our field data. There are remarkably few artifacts and those we do have are uniformly utilitarian in nature. Those citizens with less opportunity continued to opt for rentals as a way of offsetting risks that came with owning the land (from investing in infrastructure/equipment to unpredictable weather or pest related effects on harvests). This was particularly true in the early years of the transition (Caldora 1960) and is likely an accurate reflection of the rather superficial attempt to dismantle feudalism, which generally resulted in the major players (church, municipality or the few wealthy individuals) buying up the lands that were put up for auction. As we continue our work, we will determine if this can be more clearly associated with the quality and position of individual plots and the remains of agricultural infrastructure and homes across the landscape.

The transition from a more extensive and diversified usage of the landscape directed largely by the church's desires may not have seemed as onerous to Bovans as cooperation with the administration in Naples. This was something that set them apart with regard to other ex-feudal territories. Their long history of intricate ties to the local bishop may have led them to resist requests from Naples in subtle ways while essentially remaining subordinate to the church, the major landholder. Leaving fields under-cultivated or fallow, letting rural homes and structures degrade (or repurposing them as storage), may have contributed to an impression of abandonment (intentional or not) to those in the imperial capital or the outside world in general. This may then have become a tradition of sorts and a barrier to outside interference that appears to have ramifications down to the present day. Contemporary changes reflect new political pressures, this time not from an imperial regime but from the EU. Once again, the citizens of the area are adapting, and at times resisting the pressures from outside. The deliberate burning of fields and forests may reflect some interpersonal agendas. It may also reflect ways of expressing dissatisfaction with unwanted policies imposed by outsiders, which may seem to Bovans like just another attempt to exploit the area with little return. The same is true for the maintenance (or lack thereof) of field structures and public infrastructure. The integration of survey data and archival materials has highlighted the difficult economic and social circumstances experienced by many Bovans, providing deeper knowledge of the social, economic and environmental dynamics of the post-medieval period. Future research will strive to enhance our understanding of both the more distant past and the present.

Acknowledgments The research presented here owes its genesis to the Bova Marina Archaeological Project directed by John Robb, Lin Foxhall, David Yoon, and Meredith Chesson. Their financial support and discussions with project participants has been invaluable. Thank you to David and Lin for sharing some of the applicable survey data, to Hamish Forbes for many useful conversations about rural life and to both Meredith and Hamish for early editorial critiques. Thanks are also due to, Helen Farr, Kostalena Michiklaki, Fran Halper, Karla Layden, and Dean Kritikos for many useful insights. I am indebted to my colleagues at the Soprintendeza Archaeologica di Reggio, the Archivio di Stato di Reggio, and the Archivio di Stato di Napoli for assistance finding and deciphering archival materials and to Doortje Van Hoven for work on preliminary investigations of this data. Finally, I am grateful to Maura Flannery of the Center for Teaching and Learning and Anne Geller of the Writing Across the Curriculum program at St. John's University for organizing writing retreats that have helped me to finish this work and gain valuable ideas from the cross-disciplinary discussions with my colleagues. Thanks are also due to reviewers of earlier versions of this paper for the time they took to share their thoughtful critiques with me. All translations from the Italian are mine as are all photographs/images unless otherwise marked. 
Open Access This article is distributed under the terms of the Creative Commons Attribution License which permits any use, distribution, and reproduction in any medium, provided the original author(s) and the source are credited.

\section{References}

Alagna, D. (1744). Breve e Comprendiose Topografie o Sia Comendose Notizie Ecclesiastiche e Civile Della Citta' Di Bova Del Sacerdote Domenico Alagna Poste in Bello Da Don Pasquale Autilitano. Copied July 1862. Vol. Archivio Nesci \# 24 Busta 51, Archivo di Stato di Reggio Calabria.

Angioni, G. (1982). Sa Laurera. Il lavoro cotadino in Sardegna, EDES, Cagliari.

Arlacchi, P. (1983). Mafia, Peasants, and Great Estates: Society in Traditional Calabria, Cambridge University Press, Cambridge.

ASN. (1742). Reggio Camera della Sommaria, Catasti Onciari, Prima Calabria Ulteriore, Bova. ONC, Archivo di Stato, Napoli.

ASRC, C. (1807). Catasto Murattiano. Busta 3bis, Archivo di Stato di Reggio Calabria.

ASRC, S. (1822). Stato di Sezione. Contribuzione Fondari. Processo verbale della divisione del territorio di Bova in otto sezione. Inv 742, Archivo di Stato di Reggio Calabria.

ASRC. (1826). Prodotti della montagna indivisa Bova-Africo-Roghudi. Busta 13 Inv. 3 \# 557, Archivo di Stato di Reggio Calabria.

ASRC. (1832a, Gennaio). Copia estratta dalla tassa delli usari per pascolo delle montagne riguardando propriatari di animali del Comune di Africo. Busta 14 Inv 3 \#587, Archivo di Stato di Reggio Calabria.

ASRC. (1832b). Tassa tra gli usari del fondo montagna. Busta 14 Inv 3 \#587, Archivo di Stato di Reggio Calabria.

ASRC. (1842a). Fitto dell'erbaggio. Busta 14 Inv 3 \#620, Archivo di Stato di Reggio Calabria.

ASRC. (1842b). Fitto di Beni Communale. Busta 14 Inv 3 \#619, Archivo di Stato di Reggio Calabria.

ASRC. (1908). Rilievi per Bova Marina. Busta 273 Inv 24/1 \# 26 Municipio di Bova \# 1993, Archivo di Stato di Reggio Calabria.

Assante, F. (1997). Contratti e rapporti di produzione tra '700 e '800. In Placanica, A. (ed.), Storia Della Calabria Moderna e Contemporanea, vol. II, Gangemi Editorepp, Reggio Calabria, pp. 253-268.

Athanassopoulos, E. F. (2004). Historical archaeology of medieval mediterranean lanscapes. In Athanassopoulos, E. F., and Wandsnider, L. (eds.), Mediterranean Archaeological Landscapes: Current Issues, University of Pennsylvania Museum of Archaeology and Anthropology, Philadelphia, pp. 81-98.

Athanassopoulos, E. F. (2010). Landscape archaeology and the medieval countryside: settlement and abandonment in the Nemea region. International Journal of Historical Archaeology 14: 255-270.

Athanassopoulos, E. F., and Wandsnider, L. (eds.) (2004). Mediterranean Archaeological Landscapes: Current Issues, University of Pennsylvania Museum of Archaeology and Anthropology, Philadelphia.

Autilitano, S. P. (nineteenth century). Libro e piano, o sia platea dove si annotano tutti gli beni di mia casa, e sono li seguenti videli' et fatto da me Salverio Autilitano. Archivio Nesci \# 19 busta 51, Archivo di Stato di Reggio Calabria.

Barker, G. (1995). A Mediterranean Valley: Landscape Archaeology and Annales History in the Biferno Valley, Leicester University Press, London.

Bizzocchi, R. (2009). Storia D'Europa e del Mediterraneo dal Medioevo All'Eta' della Globalizzazione, vol. $\mathrm{X}$, Salerno, Roma.

Boschi, E., and Bordieri, F. (1998). Terremoti d'Italia, Baldini Castoldi Dalai, Milano.

Botwick, B., and McClane, D. A. (2005). Landscapes of resistance: a view of the nineteenth-century Chesapeake Bay oyster fishery. Historical Archaeology 39: 94-112.

Bova Marina Archaeological Project. (2011). Bova Marina Archaeological Project Reports. <http://www.arch. cam.ac.uk/ jer39/BMAP/Reports.html>

Branton, N. (2009). Landscape approaches in historical archaeology: the archaeology of places. In Majewski, T., and Gaimster, D. (eds.), International Handbook of Historical Archaeology, Springer, New York, pp. 51-65.

Butzer, K. W. (1982). Archaeology as Human Ecology: Method and Theory for a Contextual Approach, Cambridge University Press, Cambridge.

Caldora, U. (1960). Calabria Napoleonica (1806-1815), F. Fiorentino, Napoli.

Caridi, G. (1997). Rapporti di produczione e contratti agrai dal cinquecento al seicento. In Placanica, A. (ed.), Storia della Calabria Monderna e Contemporanea, vol. II, Gangemi Editore, Reggio Calabria, pp. 227-249.

Ciaccio, C. (1987). La casa rurale in Aspromonte. In Manzi, E., and Ruggiero, V. (eds.), La Casa Rurale nella Calabria, Leo S. Olschki, Firenze, pp. 427-446. 
Davies, S., and Davis, J. L. (2007). Between Venice and Istanbul: Colonial Landscapes in Early Modern Greece. Hesperia Supplemental 40, American School of Classical Studies at Athens, Princeton.

Davis, J. L. (1991). Contributions to a Mediterranean rural archaeology: historical case studies from the Ottoman Cyclades. Journal of Mediterranean Archaeology 4: 131-216.

de Filippis, V. (1999). De’Terremoti della Calabria Ultra nel 1783 \& 1789, Centro Bibliographico Calabrese, Catenzaro.

de Saint Non, J. C. R. (1978). In Valenti, G. (ed.), La Calabria dell'abate di Saint-Non, Effe Emme, Chiaravalle Centrale.

Di Scala, S. M. (1995). Italy: From Revolution to Republic, 1700 to the Present, Westview Press, Boulder.

Doonan, O., Bauer, A., Sherratt, S., Casson, A., and Conrad, M. (2012). Stepping into the Mountains: Sinop Regional Archaeological Project 2011 Report. Presented at the Annual Meeting of the Archaeological Institute of America, Philadelphia.

Doorn, P. K. (1985). Geographical analysis of early modern data in ancient historical research: the example of the Strouza Region Project in central Greece. Transactions of the Institute of British Geographers 10: 275-291.

Dyson, S. L., and Rowland, R. J. (2007). Archaeology and History in Sardinia from the Stone Age to the Middle Ages: Shepherds, Sailors, and Conquerors, University of Pennsylvania Museum of Archaeology, Philadelphia.

Ferrante, N. (1993). Il Monte dei Pegni. Historia - Rivista Trimestrale di Cultura 46(2): 80-84.

Forbes, H. (2006). Post-medieval landscapes: standing buildings. In Foxhall, L. (ed.), Bova Marina Archaeological Project Preliminary Report 2006 Season, University of Leicester, Leicester, pp. 51-53.

Forbes, H. (2007a). Meaning and Identity in a Greek Landscape: An Archaeological Ethnography, Cambridge University Press, Cambridge.

Forbes, H. (2007b). Early modern Greece: liquid landscapes and fluid populations. In Davies, S., and Davis, J. L. (eds.), Between Venice and Istanbul: Colonial Landscapes in Early Modern Greece, Hesperia Supplemental 40: 111-136. American School of Classical Studies at Athens, Princeton.

Foxhall, L. (2000). The running sands of time: archaeology and the short-term. World Archaeology 31: $484-498$.

Foxhall, L. (2006). Bova Marina Archaeological Project, Preliminary Report 2006 Season, University of Leicester, Leicester.

Foxhall, L., Lazrus, P., Michaelaki, K., Robb, J., Van Hove, D., and Yoon, D. (2007). The changing landscapes of Bova Marina, Calabria. In Fitzjohn, M. (ed.), Upland Lanscapes in Sicily and Southern Italy, vol. 13, Accordia Research Institute, University of London, London, pp. 19-34.

Gaimster, D. (2009). An embarrassment of riches? Post-medieval archaeology in northern and central Europe. In Gaimster, D., and Majewski, T. (eds.), International Handbook of Historical Archaeology, Springer, New York, pp. 525-547.

Galanti, G. M. (1806). Calabria 1792: Diarii, Relazioni e Lettere di un Visitatore Generale, Elea Press, Salerno.

Galt, A. (1991). Far from the Church Bells: Settlement and Society in an Apulian Town, Cambridge University Press, Cambridge.

Gatto, A. (1994). Saggio di Economia Campestre per la Calabria Ultra; Istruzioni sulla nuova Manifattura dell'olio Introdotta nella Calabria/Domenico Grimaldi, Abramo, Catanzaro.

Gelichi, S., and Librenti, M. (2007). Constructing Post-Medieval Archaeology in Italy: A New Agenda. Proceedings of the International Conference, Venice, 24th and 25th November 2006, All'insegna del giglio, Borgo San Lorenzo.

Gibson, E. (2007). The archaeology of movement in a Mediterranean landscape. Journal of Mediterranean Archaeology 20: 61-87.

Given, M. (2004). The Archaeology of the Colonized, Routledge, London.

Guido, D. (2002). Enciclopedia dei Comuni della Calabria, Finanzaria Editorile, Castrolibero.

Horden, P., and Purcell, N. (2000). The Corrupting Sea: A Study of Mediterranean History, Blackwell, Oxford.

Horning, A. (2007). Materiality and mutable landscapes: rethinking seasonality and marginality in rural Ireland. International Journal of Historical Archaeology 11: 358-378.

Johnson, M. (2007). Ideas of Landscape, Blackwell, Oxford.

Kasdagli, A. (2007). Notarial documents as a source for agrarian history. In Davies, S., and Davis, J. L. (eds.), Between Venice and Istanbul: Colonial Landscapes in Early Modern Greece, Hesperia Supplemental 40: 55-70. American School of Classical Studies at Athens.

LaCava, E. (2001). Bova Memoria del Passato. La Storia, Vescovi, La Chiesa, Enotria, Reggio Calabria.

Lazrus, P. K. (1992). Settlement and Land-Use in Two Regions of Sardinia, the Gerrei and the Sinis. Doctoral dissertation, Boston University, Boston.

Lazrus, P. (2005). Post-medieval landscapes: archival research. In Foxhall, L. (ed.), Bova Marina Archaeological Project Preliminary Report 2005 Season, University of Leicester, Leicester, p. 59. 
Lazrus, P. (2006). Post-medieval landscapes: archival research. In Foxhall, L. (ed.), Bova Marina Archaeological Project Preliminary Report 2006 Season, University of Leicester, Leicester, p. 51.

Lazrus, P., and Robb, J. (1998). History of the modern landscape. In Robb, J. (ed.), Bova Marina Archaeological Project: Survey and Excavations at Umbro Preliminary Report 1998 Season, University of Southampton, Southampton.

Lear, E. (2003). Diario di un Viaggio a Piedi. Reggio Calabria e la Sua Provincia (24 luglio - 5 settembre 1847), Laruffa Editore, Reggio Calabria.

Manacorda, D. (ed.) (1985). Il Giardino del Conservatorio di S. Caterina della Rosa, Edizioni all'Insegna del Giglio, Firenze.

Manzi, E., and Ruggiero, V. (1987). La Casa Rurale nella Calabria, L.S. Olschki, Firenze.

Misafari, E. (1973). Storia Sociale della Calabria, Jaca Book, Milano.

Mitchell, B. R. (2008). International Historical Statistics: Europe, 1750-2000, Palgrave Macmillan, New York.

Molinaro, N., and Solimene, A. (2006, 2007). Bicentenario. <http://bicentenario.provincia.napoli.it/depocase.html>.

Pasquale, G. A. (1863). Relazione sullo Stato Fisico: Economico Agrario della Prima Calabria Ulteriore, Tipolgrafia R. Albergo d'Poveri, Napoli.

Postpichi, D. (ed.) (1985). Catalogo dei Terremoti Italiani dall'anno 1000 al 1980, Consiglio nazionale delle ricerche, Gruppo catalogo dei terremoti, Roma.

Principe, I. (1997). Citta' e territorio in Calbria: organizazione di un periferia. In Placanica, A. (ed.), Storia della Calabria Moderna e Contemporanea, vol. II, Gangemi Editore, Reggio Calabria, pp. 187-205.

Rao, A. M. (1992). Calabria nel settecento. In Placanica, A. (ed.), Storia della Calabria Moderna e Contemporania, Gangemi Editore, Reggio Calabria, pp. 332-350.

Robb, J. (1997). Bova Marina Archaeological Project: Survey and Excavations at Umbro Preliminary Report 1997 Season, University of Southampton, Southampton.

Robb, J. (1999). Bova Marina Archaeological Project: survey and Excavations at Umbro. Preliminary Report, 1998 Season, University of Southampton, Southampton.

Roberts, B. K. (1996). Landscapes of Settlement: Prehistory to the Present, Routledge, London.

Rocheleau, B., Thomas-Slayter, D., and Edmunds, D. (1995). Gendered resource mapping: focusing on women's spaces in the landscape. Cultural Survival Quarterly 19(4): 62-68.

Russo, F. P. (1961). Storia della Archidiocesi di Reggio Calabria, Laurenziana, Napoli.

Sirago, M. (1997). Organizzazione e transformazione della feudalita. In Placanica, A. (ed.), Storia della Calabria moderna e contemporanea, vol. II, Gangemi Editore, Reggio Calabria, pp. 271-288.

Snead, J. E., Erickson, C. L., and Darling, J. A. (2009). Making human space: the archaeology of trails, paths, and roads. In Snead, J. E., Erickson, C. L., and Darling, A. J. (eds.), Landscapes of Movement: Trails, Paths, and Roads in Anthropological Perspective, University of Pennsylvania Museum of Archaeology, Philadelphia, pp. 1-19.

Taruffi, D., Nobile, L. D., and Lodi, C. (1908). La Questione Agraria e L'Emigrazione in Calabria, Presso G. Barbera, Firenze.

Van Dommelen, P. (1997). Colonial constructs: colonialism and archaeology in the Mediterranean. World Archaeology 28: 305-323.

Yoon, D. (2006). Field survey. In Foxhall, L. (ed.), Bova Marina Archaeological Project Preliminary Report 2005, University of Leicester, Leicester, pp. 11-16.

Yoon, D. (2012). Postmedieval Evidence from the Bova Survey, 1999-2009. Unpublished manuscript in possession of author.

Zarinebaf, F., Bennet, J., Davis, J. L., Gorogianni, E., Harlan, D. K., Kiel, M., MacKay, P. A., Walldrot, J., and Wolpert, A. D. (2005). A historical and economic geography of Ottoman Greece. Hesperia Supplements 34: $1-328$. 